NBER WORKING PAPER SERIES

\title{
DOES IT MATTER WHO HAS THE RIGHT TO PATENT: FIRST-TO-INVENT OR FIRST-TO-FILE? LESSONS FROM CANADA
}

\author{
Shih-tse Lo \\ Dhanoos Sutthiphisal \\ Working Paper 14926 \\ http://www.nber.org/papers/w14926
NATIONAL BUREAU OF ECONOMIC RESEARCH
1050 Massachusetts Avenue
Cambridge, MA 02138
April 2009

We are grateful to the late Kenneth Sokoloff for sharing with us his wisdom on the economics of invention. He has been the source of our inspiration on the subject matter. We have also benefited from comments offered by Leah Brooks, Jenifer Hunt, B. Zorina Khan, Naomi Lamoreaux, Mary MacKinnon, Daniel Parent and Jean-Laurent Rosenthal, as well as seminar participants at McGill and Toronto. We would like to thank Lingni Boon, Margaret Gales, Murlinda Kachuri, Mari-Ann Larsen-Volay and William Oman for their research assistance, as well as Yun Xia for his programming assistance in the CIPO data collection. Sutthiphisal acknowledges financial supports from Fonds québécois de la recherche sur la société et la culture (FQRSC) and the Social Sciences and Humanities Research Council of Canada (SSHRC). The views expressed herein are those of the author(s) and do not necessarily reflect the views of the National Bureau of Economic Research.

NBER working papers are circulated for discussion and comment purposes. They have not been peerreviewed or been subject to the review by the NBER Board of Directors that accompanies official NBER publications.

(C) 2009 by Shih-tse Lo and Dhanoos Sutthiphisal. All rights reserved. Short sections of text, not to exceed two paragraphs, may be quoted without explicit permission provided that full credit, including (c) notice, is given to the source. 
Does it Matter Who Has the Right to Patent: First-to-invent or First-to-file? Lessons From

Canada

Shih-tse Lo and Dhanoos Sutthiphisal

NBER Working Paper No. 14926

April 2009

JEL No. O3

\begin{abstract}
$\underline{\text { ABSTRACT }}$
A switch to a first-to-file patent regime from its first-to-invent system has become imminent for the U.S. To learn about probable effects of such a policy change, we examine a similar switch that occurred in Canada in 1989. We find that the switch failed to stimulate Canadian R\&D efforts. Nor did it have any effects on overall patenting. However, the reforms had a small adverse effect on domestic-oriented industries and skewed the ownership structure of patented inventions towards large corporations, away from independent inventors and small businesses. These findings challenge the merits of adopting a first-to-file patent regime.
\end{abstract}

Shih-tse Lo

McGill University

Department of Economics

855 Sherbrooke Street West

Montreal, Quebec H3A, 2T7

CANADA

shih-tse.lo@mcgill.ca

Dhanoos Sutthiphisal

McGill University

Department of Economics

855 Sherbrooke Street West

Montreal, Quebec H3A, 2T7

CANADA

and NBER

dhanoos.sutthiphisal@mcgill.ca 


\section{INTRODUCTION}

Patent protection has long been regarded as an important instrument to promote technological progress, and thereby long-run economic growth. A vast volume of theoretical literature has focused on optimal patent design. Only recently have scholars started empirically examining the effects of patent systems on invention and innovation (Kortum and Lerner, 1999; Sakakibara and Branstetter, 2001; Moser, 2005; Lo, 2008). While these studies provide some insight into the impact of various features of patent protection (for example, patent length, scope and enforcement) on invention and innovation, economists have largely overlooked the most fundamental aspect of the patent system: who is entitled to the property rights to an invention. ${ }^{1}$

Should the patent rights to an invention be granted to the party first to disclose the invention before the patent office, or should they be given to the "true" inventor - the first person who developed the invention? The rule that awards patents to true inventors is referred to as "first-to-invent." On the other hand, "First-to-file” grants the patent rights to an invention to the person who first files a patent application for that invention, whether or not he is the true inventor. The first-to-file rule was first adopted by European countries and has gradually become the international standard. Virtually every country in the world employs a first-to-file patent system today. In contrast, the U.S. has embraced the idea of first-to-invent ever since its earliest patent statute in $1790 .^{2}$

${ }^{1}$ There is virtually no work on this subject other than two theoretical studies by Scotchmer and Green (1990), and Miyagiwa (2007). Although Johnson and Popp (2003) conduct a relevant empirical investigation, their study is focused on how the timing of patent disclosure affects the rate of technology diffusion, not a switch between the two priority claim rules: first-to-file and first-to-invent.

${ }^{2}$ Countries, like Great Britain, that historically allowed patents of importation were early adopters of first-to-file. These countries awarded patent rights to individuals who may simply have imported the technology from another country. In contrast, the American system has always favored inventors. Moreover, under its early patent statutes, the U.S. kept the cost of filing patent applications surprisingly 
This unique tradition of the U.S. patent system has led to a recurring discussion among inventors, scholars and policy makers over whether the U.S. should abandon its first-to-invent practice and conform to the global norm by switching to a first-to-file system. ${ }^{3}$ Attempts have been made by members of the Congress to switch to a first-to-file system, but all have failed (Patent Reform Act of 1967, Patent System Harmonization Act of 1992, Patent Reform Act of 2005). However, the discussion has escalated and turned into a heated debate recently as U.S. law makers are once again considering reforming the U.S. patent system. A switch to the first-to-file doctrine is one of the key features of the Patent Reform Act of 2007. The proposed bill was passed by the House of Representatives in September 2007. This was the first time that the House agreed to a patent reform bill intended to change the U.S. patent system to a first-to-file system. ${ }^{4}$ However, it has been shelved in the Senate since April $2008 .^{5}$

Perhaps, one of the reasons why the 2007 Patent Reform Act is stalled in the Senate is that it is unclear how such a change will affect inventive activity. The first-toinvent principle has often been criticized for its lack of an incentive for inventors to promptly reveal their inventions. In contrast, the first-to-file doctrine encourages early patenting, and thereby disclosure. It accelerates the dissemination of relevant technical information. This may subsequently raise the level of inventive activity, and hence, lead to more technological improvements.

\footnotetext{
low. These features may explain why the rate of inventive activity in the U.S. surpassed Britain and other European countries whose patent systems were less democratic. See Khan (2005) and Martin (2006) for the development of the U.S. patent system.

${ }^{3}$ For discussion on legal perspectives, see Frost (1967), and Harbers (1968). For news media coverage, see, for example, Sekiguchi (1989).

${ }^{4}$ The House did not pass Patent Reform Act of 1967, Patent System Harmonization Act of 1992 and Patent Reform Act of 2005. See U.S. Congressional Record, Vol. 113, 138 and 151.

${ }^{5}$ See Gross (2008).
} 
While this is arguably a strong case for embracing the first-to-file rule, there are also ample reasons in favor of continuing with the first-to-invent regime. The first-toinvent principle promises patent rights to the true inventor of an invention (the person who first conceives and develops the invention). It allows him to continue working on the invention, regardless of the timing of filing a patent application. On the other hand, the first-to-file doctrine does not provide such an incentive. First-to-file instead encourages quick-filing and rewards the person who wins the race to the patent office. Consequently, a switch to a first-to-file system will dilute the incentive to carry out R\&D and may lower the overall level of inventive activity. Furthermore, large corporations have more resources to file patent applications early (and make amendments if necessary), so it is believed that under the first-to-file system such firms have an advantage in securing patent protection for their inventions relative to independent inventors and small businesses. ${ }^{6}$ The first-to-file rule may lead to a distribution of patents skewed toward businesses that are large and deep-pocketed.

Unfortunately, no empirical work is available to substantiate these claimed benefits and costs of the two doctrines, which would help us understand how the Reform, if passed and signed into law, will affect U.S. inventive activity. This paper provides the

\footnotetext{
${ }^{6}$ Under the first-to-file priority claim rule, inventors run a risk of filling incomplete and not fully worked-out patent applications. Consequently, patent systems that adopt such a rule typically allow applicants to file provisional applications, so as to supplement and amend the original applications. In 2008, an initial filing fee for a patent application in Canada was 400 CAD for large businesses and 200 $\mathrm{CAD}$ for small businesses and individual inventors. An amendment to an existing application (a provisional application) costed inventors additional $400 \mathrm{CAD}$ and there was no fee reduction for small entities. It costed inventors 310 USD to file a U.S. patent application and additional 210 USD for a provisional application. These fees were reduced by $50 \%$ for small entities. (See CIPO Canadian Patents Database and USPTO FY 2008 Fee Schedule.)

${ }^{7}$ Other arguments against a first-to-file system are centered on the scope of patents and the direction of R\&D efforts. A switch to a first-to-file system may result in patents with narrower scopes as well as redirect R\&D efforts to innovation or other minor improvements rather than basic and fundamental research (such as that in biotechnology and pharmaceutical industries). Wiggs (1991) provides more details on various arguments against or in favor of these two priority claim rules. Also, see Debari (1993).
} 
needed evidence on a switch to a first-to-file system, particularly how it influences the level and distribution of inventive activity. We explore the 1987 Canadian Patent Reforms that fundamentally changed the Canadian patent system to a first-to-file system from its original first-to-invent system. The Canadian Reforms provide a rare opportunity to learn about probable effects on the U.S. economy of adopting a first-to-file system. Not only was Canada the last industrialized country to make such a switch, but also the Canadian economy has many characteristics similar to those of the U.S. economy.

To assess the impact of the Reforms, we compare inventive activity carried out by Canadians before and after the enactment of the new law against that of Americans whose home country did not undergo any significant change in its patent system during that time. Our analysis is carried out at the industry level. We use R\&D spending to measure inventive input. As an indicator of inventive output, we employ patents granted by the Canadian Intellectual Property Office (CIPO) and by the United States Patent and Trademark Office (USPTO) as well as patent applications to the European Patent Office (EPO). The use of patenting data in Canada and abroad (in the U.S. and Europe) helps us disentangle the twin effects of a patent reform on patenting: the real change in inventive output and in the propensity to use domestic patent protection. Any variation in patenting abroad around the time when a domestic policy shift takes place is likely to reflect real changes in inventive output rather than changes in the propensity to patent domestically (provided there is no major change in the patent system or other relevant policies abroad).

We find that the 1987 Canadian Patent Reforms did not change R\&D efforts by Canadian inventors. However, the Reforms seemed to have a small negative impact on patenting of Canadian domestic-oriented industries in Canada, the U.S. or Europe. An 
exploration into the ownership structure of invention further reveals that the new first-tofile system seemed unfavorable to individual inventors and small businesses. It skewed the ownership of patented inventions towards large corporations. These findings suggest that a switch from first-to-invent to first-to-file may harm a country's inventive activity.

Perhaps, it is thus not a coincidence that the largest engineering professional organization in the U.S. - the U.S. Institute of Electrical and Electronics Engineers (IEEE-USA) in its letter to members of the Congress regarding the Patent Reform Act of 2007, stated:

We believe that much of the legislation is a disincentive to inventiveness, and stifles new businesses and job growth by threatening the financial rewards available to innovators in U.S. industry. Passage of the current patent reform bill language would only serve to relax the very laws designed to protect American innovators and prevent infringement of their ideas. $^{8}$

\section{BACKGROUND}

\section{A. How Does Patent Protection Work?}

A patent to an invention provides the patent holder the right to exclude others from manufacturing, using, selling and importing the invention or products in which the invention is embedded. An international patent system would thwart infringement, and increase expected (as well as realized) profits to inventors. Unfortunately, patent law is a national law. Rights granted by a country's national patent office are only applicable within the territory of that country. Thus, a patent granted in one country cannot be substituted for a patent granted in another.

\footnotetext{
${ }^{8}$ Meredith and Grzelak (2007), p.1.
} 
An inventor, seeking patent protection to an invention in multiple countries, must take out an application with the national patent office in each of these countries. However, the decision on where to patent an invention is largely influenced by where the invention will be used and where the products made with the invention will be manufactured, sold and franchised. This implies that an inventor's decision to file a patent application in one country is not always highly correlated with his decision to apply elsewhere. Hence, a change in one country's patent policy may not alter the tendency of its inventors to seek patent protection in other countries, unless such a change in patent law leads to a shift in sales destinations and manufacturing locations.

\section{B. The 1987 Canadian Patent Reforms}

Historically, the Canadian patent system was largely influenced by the American system. ${ }^{9}$ The Canadian Patent Act of 1869 embraced the U.S. first-inventorship principle, awarding patent rights to the first person to invent. Canada also followed in the footsteps of the U.S. rather than Great Britain by instituting a system in which every patent application was subject to a thorough examination. From its enactment in 1869 to the early 1980s, the system had undergone a few amendments, but the fundamental features remained similar.

The biggest change to the Canadian Patent Law to date came in 1987. The pressure to change the system largely came from abroad. Concerns were raised by Canada's major trading partners in Europe and Japan that all adopted a first-to-file

\footnotetext{
${ }^{9}$ The early patent systems in British North America were regulated by individual colonies. The earliest patent practice can be traced as far back as 1791 when the Legislature of Lower Canada (now Quebec) issued a patent to Samuel Hopkins and Angus MacDonnel. (Samuel Hopkins was also awarded the first U.S. patent for the same invention in 1790.) A patent system at the federal level was created in 1869, shortly after Confederation. See White (2008).
} 
system. Also, the pharmaceutical industry, particularly multi-national drug companies, pleaded for an extension of patentable subject matter to pharmaceutical products as well as a tightening of compulsory licensing of generic drugs. ${ }^{10}$ As a result, in June 1986, Bill C-22, an amendment to the Patent Act, was introduced to the Canadian Parliament. The new law was more in harmony with those employed by European industrialized countries. The Reform bill was passed by the House of Commons on May 6, 1987 and by the Senate on November 19 of the same year. The amendment came into effect on October 1, 1989. ${ }^{11}$

The 1987 Canadian Patent Reforms have made two major changes to the Canadian patent system. The first is that pharmaceuticals are now deemed patentable. The second and more fundamental change is the adoption of a first-to-file system. The new patent law was very much modeled on the system instituted by the European Patent Office. Under the amendment, Canada no longer awards patent protection to the first person to invent an invention but rather to the first person to file a patent application for such a creation. As the spirit of the first-to-file principle is to facilitate the diffusion of new and useful arts, the amendment required mandatory disclosure of patent applications. Every application is laid open to the public eighteen months after the date of filing. ${ }^{12}$ The practice of maintenance fees (or renewal fees) for both patent grants and applications, used by the European Patent Office, was also introduced, so as to make outdated and

${ }^{10}$ Compulsory licensing is defined as "when a government allows someone else to produce the patented product or process without the consent of the patent owner" (World Trade Organization, n.d.). The 1969 amendment made compulsory licenses of imported pharmaceuticals possible and kept the royalties at the rate no greater than $4 \%$ of net selling prices of these imported inventions, so as to promote growth of Canada's generic drug industry as well as create affordable medicines for Canadians.

${ }^{11}$ See Jordan (2005), pp. 29-34.

${ }^{12}$ USPTO used to require no disclosure of information on all patent applications. Only after a patent was finally issued, the information on the invention was made public. Such a practice has been abandoned for patent applications which are also filed outside the U.S. ever since the American Inventors Protection Act of 1999. 
obsolete patents as well as trivial applications fall into the public domain sooner. Such a feature increased the cost of patenting, but the added cost was kept relatively low in the initial period. The annual payment for a patent application was 100 Canadian dollars during the first four years and the figure for a patent grant was 150 dollars. There were, furthermore, $50 \%$ fee reductions for small businesses and individual inventors. It was only in the later period that the added cost became substantial because of the increasing maintenance fee schedule. ${ }^{13}$ Lastly, the term of a patent changed from 17 years from the grant date to 20 years starting from the filing date. ${ }^{14}$

\section{The Canada-U.S. Free Trade Agreement}

To assess the impact of the 1987 Patent Reforms, it is important to consider whether there were other policy shifts that may also affect Canadian inventive activity around the same time. One important policy change is worth our attention: the CanadaU.S. Free Trade Agreement. In 1987, an agreement between the U.S. and Canada was reached to liberalize cross border trade. The agreement became effective in January 1, 1989. It included no chapter on patent rights although issues pertaining to copyrights, particularly cross-border broadcasting, were raised.

In response to the creation of the free trade zone, inventive activity performed by Canadian businesses may change. However, there is good reason to believe that any change in inventive activity should be small. By the 1980s, the two economies, Canada and the U.S., were already highly integrated, and each had become the other's largest trading partner. In fact, the U.S., on the eve of the agreement, was the destination of more

\footnotetext{
${ }^{13}$ For example, for a patent filed in 1990, the maintenance fees ranged from 150-250 CAD during the fifth and fourteenth years, and became 450 CAD from the fifteenth year onwards.

${ }^{14}$ See Duy (2001) for the development of the Canadian Patent System.
} 
than $70 \%$ of Canadian exports and more than $80 \%$ of the shipments faced zero nominal tariffs across border (Wilkinson, n.d.). Meanwhile, Canada absorbed 21.5\% of all U.S. exports in $1989 .{ }^{15}$ Moreover, tariff cuts imposed by the Canada-U.S. Free Trade Agreement raised total factor productivity for the entire manufacturing sector by merely 0.2 percent and production workers’ wages by 0.3 percent annually (Trefler, 2004).

\section{Other International Policies that May Affect Our Investigation}

Policy changes that happened in the U.S. in the 1980s and early 1990s may also affect our investigation of changes in Canadian inventive activity due to the 1987 Patent Reforms. There were two major changes in the U.S. patent policy, and they both occurred in 1982. One is the creation of the U.S. Court of Appeals of the Federal Circuit, which is a special appellate court to handle patent litigation. The other is the introduction of patent maintenance fees for granted patents. The establishment of the new court is regarded by scholars, such as Merges (1992), as the beginning of the "pro-patent" period in the U.S. in the late 20th century. The introduction of patent renewal fees in the U.S. did not discourage inventors from patenting there. The numbers of USPTO patent applications and grants have grown rapidly since the early 1980s, especially for foreigners. ${ }^{16}$

Other events that may be of concern are the North American Free Trade Agreement (NAFTA) and the World Trade Organization's (WTO) Agreement on TradeRelated Aspects of Intellectual Property Rights (TRIPS). NAFTA came into effect in 1994. The Canada-Mexico-U.S. three-way treaty included some provisions on patent

\footnotetext{
${ }^{15}$ U.S. International Trade Commission (n.d.).

${ }^{16}$ In contrast to many renewal systems in which maintenance fees are paid every year, maintenance fees for a U.S. patent are due three and a half, seven and a half, and eleven and a half years after the grant date. (There is no renewal fee for patent applications in the U.S.) This introduction of maintenance fees in the U.S. has generated little discussion in academia and in policy circle, except a theoretical study by Scotchmer (1999).
} 
protection. These provisions, however, mainly focused on patent protection in Mexico. The concern about Canada's patent system only lay in provisions that regulated how the federal and provincial governments could use patented inventions. In contrast, inventive activity of Canadians may be influenced more by the multi-national treaty on intellectual property, TRIPS, that was finalized in April 1994. To comply with it, the Canadian government introduced an implementation act in April 1995. The amendment, as regards patent rights, was centered on the use of patented semiconductor technologies by governments. The new law became effective in 1996. Although the agreement may not have a direct impact on Canadian inventive activity through the new Canadian patent law, it substantially strengthened intellectual property rights protection around the world, and this may have indirectly affected Canadian inventive activity.

Consequently, to assess the impact of the Reforms on Canadian inventors while isolating possible confounding effects caused by shifts in U.S. patent policy and international treaties, our analysis focuses on inventive activity during 1983 and 1994.

\section{EMPIRICAL STRATEGIES}

\section{A. Measuring Changes in Inventive Activity}

A switch from the first-to-invent to the first-to-file doctrine has potential costs as well as benefits. The basis for the first-to-file principle is to facilitate knowledge diffusion through early disclosure. With a larger amount of newer and relevant technical knowledge revealed, the amended system should have raised the productivity of inventive input, and hence there should have been more inventive output (for example, number of patents awarded) given the same amount of input after the switch. In contrast, the essence of the first-to-invent rule is all about providing the right incentive to inventors to carry 
out inventive activity. A switch to the first-to-file rule may dilute such an incentive and lead to a decrease in inventive efforts and thereby inventive output. Furthermore, inventive input may be channeled away from fundamental research towards applied research and product innovation, which is likely of a lower degree of novelty and may not be patentable. In other words, the number of patent grants given the same amount of inventive input may decline as well. If the loss due to a diluted incentive overshadows the gain from more rapid knowledge diffusion, there would be a decrease in inventive efforts and outputs in the post-reform years. On the other hand, if the more rapid knowledge diffusion outweighs the diluted incentive, we would observe an increase in inventive outputs.

To examine the effects of the switch, we employ regression analysis. Following prior work, such as Pakes and Griliches (1980), we use R\&D spending as a measure for inventive input. Ideally, we should conduct the analysis at the firm level. Unfortunately, R\&D information at such a level is only available for a small set of firms, often large or publicly traded. Consequently, our analysis is at the industry level, and the "input" equation can be written as:

$$
\begin{aligned}
R \& D_{i t}=\beta_{0}+ & \beta_{1} \cdot G D P_{i t}+\beta_{2} \cdot E X P O R T_{i t} \\
& +\sum_{i}\left(\alpha_{i} \cdot D_{i}\right)+\sum_{t}\left(\delta_{t} \cdot Y E A R_{t}\right)+\varepsilon_{i t}
\end{aligned}
$$

where $R \& D_{i t}$ is real R\&D spending (in natural logarithms) for industry $i$ in year $t$. We can employ real GDP and exports (in natural log) as independent variables, in order to capture changes in R\&D spending due to the variations in them. ${ }^{17}$ Moreover, we can include a set of industry dummies, $D_{i}$, to control for differences across industries in

\footnotetext{
${ }^{17}$ We expect exports to reflect degrees of international competition.
} 
factors such as technological opportunities and returns to inventive activity. Finally, $Y E A R_{t}$ 's are year dummies. If the switch to the first-to-file rule had an impact, the pattern traced out by the year dummies for the post-reform period should be notably different from that for the pre-reform years.

To evaluate the impact of the Reforms on inventive output, we can use a similar regression specification to Eq. (1) on patent grants. The "output" equation can be of the following form.

$$
\begin{aligned}
\text { PATENT }_{i t}= & \beta_{0}+\beta_{1} \cdot G D P_{i t}+\beta_{2} \cdot E X P O R T_{i t}+\beta_{3} \cdot R \& D_{i t} \\
& +\sum_{i}\left(\alpha_{i} \cdot D_{i}\right)+\sum_{t}\left(\delta_{t} \cdot Y E A R_{t}\right)+\varepsilon_{i t}
\end{aligned}
$$

where PATENT ${ }_{i t}$ is the natural logarithm of the number of granted patents filed by industry $i$ in year $t$. The same regressors in Eq. (1) are employed to estimate Eq. (2). We can also include the log of real R\&D spending ( $\left.R \& D_{i t}\right)$ into the set of covariates. ${ }^{18}$

Patents vary in their utility as well as social and private value. Using patent counts to measure inventive "output" may be an issue for our investigation of the Reforms as one of the many arguments against a switch to a first-to-file system is that such a change will result in more minor improvements and fewer fundamental inventions. To address this measurement issue, we can modify the dependent variable in Eq. (2) by weighting the patent count with a measure of patent value.

${ }^{18}$ The decision to include R\&D spending in the output equation is an arbitrary one. Conceptually, if we believe both $R \& D$ spending and patenting reflect the level of inventive activity, R\&D spending should not enter into Eq. (2). On the other hand, if we would like to examine how much the output will be affected holding the input constant, Eq. (2) should include R\&D spending. Most prior studies, such as Pakes and Griliches (1984) and Gallini et al. (2006), include R\&D spending in their patenting regression, and hence we adopt the same practice. Our results do not change qualitatively whether we add R\&D spending in our output regression or not. We also follow Gallini et al. (2006) in using contemporaneous R\&D spending. Prior work, such as Hall and Ziedonis (2001), concludes that contemporaneous R\&D is highly correlated with its lags within firms. In fact, our results remain similar when we use lagged R\&D spending. 
Prior work, such as Trajtenberg et al. (1997) and Lanjouw and Schankermann (2004), has suggested several methods to measure patent value or quality. There are two main approaches. The first explores to what extent a patent inspires subsequent inventions. Such information can be drawn from patent documents, which reveal past patents that the patent in question was built upon (patent citation). ${ }^{19}$ The influence of a patent on future technological improvements is thus reflected in the number of (forward) citations the patent receives (Trajtenberg, 1990).

The other approach exploits how many functions an invention can be used for or how broad it is. The breadth of a patent (or the number of different uses it has) can be measured in several ways. First, it can be measured by the number of classes involved in past patents which are cited by the patent as prior art (backward citations). ${ }^{20}$ Alternatively, we can use the total number of claims specified in a patent. ${ }^{21}$ Finally, the total number of patent classes to which a patent belongs, also reflects its breadth. ${ }^{22} \mathrm{We}$ apply all these suggested methods in our empirical analysis.

\section{B. Using Americans' Inventive Activity as a Control}

The regression specifications discussed thus far will provide some insight into the effects of the 1987 Canadian Patent Reform. Nevertheless, one needs to be cautious when

${ }^{19}$ Although patent applicants and their patent attorneys may arbitrarily list relevant past patents as references in applications, the final decision lies in the hand of patent examiners at the patent office to determine what citations a patent needs to include. Hence, patent citation appears a fair measure.

${ }^{20}$ Past patents which are cited by a patent not only reveal the relevant prior art but also serve a legal purpose in court as these antecedent patents limit the scope of the property rights of the patent. Thus, patent classes to which these cited patents provide information on the breadth of the patent.

${ }^{21}$ The claims of a patent are the building blocks of the patent. They define what the invention is and what the patent protects. The greater the number of claims embodied in a patent, the higher degree of novelty and the broader scope of the patent. See Sakakibara and Branstetter (2001).

${ }^{22}$ The register of patent classification categorizes inventions based on their functions. The more patent classes a patent covers, the more functions it can perform. Lerner (1994) shows that patents that covers more patent classes are more likely to inspire future technological advancements (be cited by subsequent patents). For the correlation or a comparison among different measures of patent value or quality, see Lerner (1994); Trajtenberg et al. (1997); and Lanjouw and Schankermann (2004). 
interpreting results from such a comparison of Canadian inventive activity before and after the policy shift. Any change, if observed, may be attributable to other factors than a change in the domestic patent policy. For example, a decline in Canadian inventive activity may be the result of a worldwide depletion of technological opportunities.

To address this issue, we use inventive activity carried out by the Americans as a baseline control group. The U.S. and Canadian economies share many characteristics. The two economies were highly integrated even before the Canada-U.S. Free Trade Agreement was announced in 1987. American and Canadian firms seemed to face comparable business conditions relevant for inventive activity, but with one important exception: inventive activity of firms would be much more influenced by their own country's intellectual property rights (IPRs) system than the other's. This is attributable to the fact that the primary market of each country was still its own domestic market. ${ }^{23}$ We would expect a change in the Canadian patent system to have much less impact on the decision of American inventors to carry out inventive activity than on that of Canadian inventors.

As a result, we can apply a difference-in-difference comparison to our analysis (Meyer 1995). Hence, Eq. (1) becomes

$$
\begin{gathered}
R \& D_{i j t}=\beta_{0}+\beta_{1} \cdot G D P_{i j t}+\beta_{2} \cdot \operatorname{EXPORT}_{i j t}+\gamma \cdot R E F O R M_{t} \cdot \text { CANADA }_{j} \\
+\sum_{i j}\left(\alpha_{i j} \cdot D_{i j}\right)+\sum_{t}\left(\delta_{t} \cdot Y E A R_{t}\right)+\varepsilon_{i j t}
\end{gathered}
$$

and Eq. (2) becomes

$$
\text { PATENT }_{i j t}=\beta_{0}+\beta_{1} \cdot G D P_{i j t}+\beta_{2} \cdot E X P O R T_{i j t}+\beta_{3} \cdot R \& D_{i j t}
$$
the U.S. in 2007 


$$
\begin{aligned}
& +\gamma \cdot \text { REFORM }_{t} \cdot \text { CANADA }_{j} \\
& +\sum_{i j}\left(\alpha_{i j} \cdot D_{i j}\right)+\sum_{t}\left(\delta_{t} \cdot Y E A R_{t}\right)+\varepsilon_{i j t}
\end{aligned}
$$

The added subscript $j$ denotes countries. $R E F O R M_{t}$ is a dummy variable, which equals 1 for the post-reform years and 0 otherwise. $C A N A D A_{j}$ is also a dummy variable, which is 1 for Canada and 0 for the U.S. A positive and significant $\gamma$ will indicate a favorable impact of the Reforms on Canadian firms' inventive efforts and output.

\section{Separating a Change in Inventive Activity from a Change in the Propensity to Patent}

There are, however, more obstacles in estimating the "output" (or patent) equations. One concern is that the Reforms also introduced annual maintenance fees for both applications and granted patents. An inventor, after filing the initial application, has to decide each year during the examination process, whether to keep the application alive by paying the required annual fees. Charging maintenance fees is unlikely to affect the initial incentive to take out patent applications (as captured by the number of initial patent applications). This is due to the fact that the renewal fees on applications during the initial period of filing were made especially low, and the length of the examination process was unknown at the time of filing. ${ }^{24}$ Nonetheless, the renewal system may decrease the number of patents eventually awarded by CIPO, especially for those of a lower value. This is because the renewal fees on applications increased substantially after the initial period, and thereby after the initial inexpensive stage inventors may decide to drop out before their applications were granted patents by $\mathrm{CIPO} .^{25}$

${ }^{24}$ See p. 9 for the renewal fees.

${ }^{25}$ In the early 1990s, the median length of a CIPO patent examination (from filing to being granted) was seven years. The figure for a USPTO application was less than three years. There is another reason why we would expect more dropped-out applications after the Reforms. Being forced to apply early, 
There may be a country difference in how the maintenance fees affected the rate at which the CIPO patent applications were kept alive, and thereby the propensity to use Canada's patent protection. Consequently, an estimation bias likely occurs when we evaluate the effects of the Reforms on inventive activity of Canadians as compared to that of Americans, given the fact that a change in the number of CIPO patents awarded to Canadians (and Americans) after the Reforms was a result of the combined effect of a real change in inventive output from the switch to a first-to-file system and a change in propensity to use patent protection caused by the implementation of maintenance fees. ${ }^{26}$

We address this issue by utilizing patents granted to Canadians and Americans by USPTO as well as patent applications they filed to EPO. The use of data on Canadian patenting abroad can help isolate the real change in inventive output from the change in the propensity to use domestic patent protection. As the decision to seek patent protection for an invention in one country is in general a separate process from the decision to patent the same invention in another, the introduction of maintenance fees and provisional applications by the Reforms may affect inventors' propensity to patent in Canada, but the new system is unlikely to affect their decision to seek protection abroad for their creations. ${ }^{27}$ However, if the Reforms had a real impact on the Canadian inventive

inventors run a risk of having to submit provisional applications. It is, in general, expensive to file amendments because the fees charged by both CIPO and patent agents were much higher than those for an initial application.

${ }^{26}$ The difference in the propensity to use patent protection could be due to a difference in the distributions of patent values between Canadian and American CIPO patents. Although the estimation bias tends to attenuate when we weight the number of patent grants with a measure of patent value in our regression, it may not be completely eliminated. See Appendix 1 for more details.

${ }^{27}$ Patenting abroad is less susceptible to policies that mainly change inventors' tendency (or propensity) to seek domestic patent protection. However, the propensity to patent abroad can be influenced by export volume, which we include as a control in our "output" regressions. 
activity, the real change in the level of inventive activity would likely spillover to patenting in foreign countries. ${ }^{28}$

\section{DATA}

The framework laid out in the last section indicates that we need to compile data on R\&D spending, patenting, exports, production and price levels for Canada and the U.S. at the industry level. ${ }^{29}$ Information on Canada’s R\&D spending is from Industrial Research and Development, 1988-1997, published by Statistics Canada. Similar information on U.S. industries is gathered from the Research and Development in Industry, 1990 and 1995, by the U.S. National Science Foundation. Production values and producer price indexes of Canadian industries are from Statistics Canada's CANSIM database. For the U.S. industries, they are from the NBER-CES Manufacturing Industry database (Bartelsman et al., 2000). Annual exports, both Canadian and American, are from the United Nation's Commodity Trade Statistics Database.

Patent data are obtained from three sources: the CIPO Canadian Patents Database, the updated version of the NBER U.S. Patent Citation Data (Hall et al., 2001 and Hall, n.d.), and the OECD.StatExtracts database. The CIPO Canadian Patents Database provides records of patents awarded by the Canadian government from 1869 to the present day, and patent applications from October 1, 1989. We collect from this database all the patent grants filed from 1983 to 1994 by Canadian inventors that were granted

${ }^{28}$ In recent years, there have been more USPTO patents awarded to Canadians than patents granted to them by Canada's own patent authority, CIPO. USPTO patents awarded to Canadian constitute a good indicator of real inventive activity performed by Canadian inventors. Indeed, patents granted to nonU.S. residents by USPTO have been widely used as a measure of inventive output or progress in science and technology in the country of origin of these inventors. See, for example, Sakakibara and Branstetter (2001), and Trajtenberg (2001 and 2002).

${ }^{29}$ We use the producer price indexes to calculate real values. We also focus on industrial R\&D spending which excludes federal funding as we are interested in how the R\&D community, particularly from the private sector, responds to a switch from a first-to-invent to a first-to-file system. 
until May 2008. Roughly 1,500 patents were granted each year to Canadian inventors who filed in the 1980s, and 1,000 patents in the early 1990s. In contrast, over 10,000 patents granted by CIPO were awarded to Americans each year in the 1980s. We thus construct a random sample of patents granted to American inventors by CIPO for the same period, since patents issued to Americans are employed as the control group. For each year, we collect CIPO patents filed by American inventors on February 1-7, June 814, August $15-21$ and October $22-28 .^{30}$ The size of the sample is about $7.7 \%$ of the total number of patents awarded to the Americans (slightly smaller than that of our CIPO patent series for Canadian inventors). For each patent, we collect information on patentee name and address, the date that the patent application was filed, assignee name (if any), number of claims, as well as patent classification. ${ }^{31}$ Similar information on patents issued by USPTO to Canadian and American inventors is retrieved from the NBER U.S. Patent Citation Data, which have additional information on patent citation. ${ }^{32}$ Lastly, we collect annual numbers of patent applications in each international patent class (IPC) filed by Canadian and American inventors to EPO from the OECD.StatExtracts. ${ }^{33}$ (See Table 1 for the annual statistics of selected key measures of inventive activity.)

To get a sense of ownership structure of Canadian inventions (in terms of firm size), we check the characteristics of all companies to which the CIPO and USPTO

${ }^{30}$ There were no federal holidays in either the U.S. or Canada during the chosen dates.

${ }^{31}$ An assignee is a person or an organization to which the rights of a patent have been assigned.

32 The updated NBER U.S. Patent Citation Data contain patents awarded by USPTO from 1963 to 2002. Truncation at year 2002 is of little consequence to most of our analysis. For example, according to the USPTO Patent Full-Text and Image Database, less than 1\% of patent grants filed by Canadian and American inventors in 1994 were awarded after 2002.

${ }^{33}$ USPTO considers a patent made by Canadian inventors if the first patentee has a Canadian address. On the other hand, CIPO regards a patent originated from Canada if at least one of the patentees has a Canadian address. To infer the origin of our patents and their inventors, we apply the USPTO definition to patents granted by USPTO, and the CIPO definition to those granted by CIPO. The EPO data series also use the address of inventors to determine the nationality of the patents, but we do not have any knowledge of which definition the database utilizes. 
patents were assigned by Canadian inventors (in www.google.com, ORBIS, FP Advisor, and Canadian Business Resource). The information retrieved on these firms includes the number of employees, annual sales, and whether they were publicly traded.

Finally, we group the data into 17 industries using probability matrixes to allocate the patents into these industries, as patents are generally categorized by patent classes (not according to the conventional standard industrial classification). See Appendix 2 for more details on the methodology used to classify the patent data, and Appendix 3 for the list of industries.

\section{RESULTS}

\section{A. How did the Reforms Affect Inventive Activity?}

Figure 1 plots total CIPO patent applications filed by Canadian inventors, total patents awarded to them, and aggregate real R\&D spending. These annual data are divided into three periods: pre-reform (prior to 1987), inter-reform (1987-1989, the Reform bill was passed by the Canadian Parliament but not yet in effect), and postreform (after 1989). The chart is normalized according to the figures of year 1989 in order to better visualize the difference in pre- and post-reform years. R\&D spending grew at a rather modest pace. In stark contrast, both patent applications and grants show more fluctuation. The annual number of patent applications in the pre-reform period was on the rise, but the growth apparently accelerated during 1987 to 1989 and suddenly slowed down and returned to the pre-reform trajectory in 1990. The number of patent grants was fairly stable throughout the pre-reform period and even in the inter-reform years. It then took a dive by nearly $40 \%$ in 1990, and stayed at a rather lower level afterwards. Figure 2 displays similar trends for Americans: a temporary surge in their patent applications in 
Canada during the inter-reform years and a significantly smaller number of patent grants since 1990.

This sudden decrease in CIPO patent grants experienced by both Canadian and American inventors is, to some extent, attributable to the introduction of maintenance fees under the new system. This new feature made it more costly to keep applications alive in the examination process, and only those of a high quality (or value) would end up being granted patent protection. As evident in Figures 3, the average success rate in receiving a patent grant for an application hit the lowest level in 1990 and continued to remain low afterwards for both Canadian and American inventors. ${ }^{34}$ Figure 4 further shows that CIPO patents awarded to both Americans and Canadians in the post-reform years were indeed of a higher average value. ${ }^{35}$ However, the decline in patenting by Canadian inventors remains pronounced even after their patent grants are weighted with some measures for patent value as illustrated in Figure 5.

Although the trends in CIPO patenting by Canadians shared many similarities with those of Americans, there existed a distinct difference in the value (or quality) of their patented inventions. Patents made by American inventors were, on average, of a higher value than those made by Canadians throughout 1979-1995 (Figure 4). Furthermore, this gap in value widened in the post-reform years. Such a finding suggests that we may face a problem when comparing the change in patenting by Canadians with that of Americans using the CIPO data (as discussed in Appendix 1).

We thus explore Canadian patenting activity in the U.S. and in Europe because they were less likely to be affected by the CIPO's introduction of application annuities.

\footnotetext{
${ }^{34}$ Another reason why the success rate declined was that a switch to a first-to-file system may lead inventors to generate more low-quality patent applications that did not meet the examination standards.

${ }^{35}$ Plots using other measures of value, such as the number of claims, reveal a similar pattern.
} 
As displayed in Figure 6, the trends in USPTO patents and EPO applications diverged from those exhibited in the CIPO data. There was no apparent decrease in patenting by Canadians after the Reforms. No significant acceleration in patenting emerged after the Reforms either. ${ }^{36}$ The patenting activity of Canadians at the aggregate level did not seem to be affected by the adoption of a first-to-file system.

We further examine the impact of this switch to a first-to-file system with regression analysis. We compare the inventive activity performed by Canadian inventors with that by their American counterparts. Our analysis is at the industry level. It covers the years from 1983 to 1994, but excludes the inter-reform period (1987-1989). The interreform period is dropped because patterns of patenting activity observed in these years did not seem to fit typical practices under either the first-to-invent or the first-to-file rule. Inventors, both Canadian and American, apparently rushed to CIPO to exploit the old regime before the new law became enforced. ${ }^{37}$

Table 2 reports the regression results. Column 1 estimates Eq. (3), which explores how the Reforms affected inventive efforts (real R\&D spending), and reveals a statistically insignificant coefficient of the interaction term between the "Reform" and the “Canada” dummies (0.069). ${ }^{38}$ This finding suggests that the switch from a first-to-invent

\footnotetext{
${ }^{36}$ One may argue that the relatively higher growth rate of Canadian patenting during the interreform years was brought about by the announcement of the Canada-U.S. Free-Trade agreement in 1987. Nonetheless, Figure 6 suggests otherwise as Canadian patenting in Europe (EPO data), where there was no free trade agreement made between Canada and major European countries, exhibited a similar pattern to Canadian patenting in the U.S.

${ }^{37}$ During 1987-1989, the number of CIPO applications increased nearly $40 \%$ for Canadians (Figure 1) and 20\% for Americans (Figure 2). Trefler (2004) employs a similar practice of dropping the inter-reform years in his evaluation of the effects of the Canada-U.S. Free Trade Agreement which was announced in 1987 and went into force in 1989.

${ }^{38}$ One may argue that this $6.9 \%$ difference in Canadian R\&D spending after the Reforms was not small even if it is statistically insignificant. Nonetheless, we believe that if the Reforms were to have a sizable impact, the coefficient of the interaction between Reform and Canada should have been statistically significant since it is a dummy variable and some continuous covariates have significant estimates.
} 
system to a first-to-file system neither diluted the incentive to carry out inventive activity nor induced Canadian industries to devote additional R\&D efforts.

Columns 2-9 estimate Eq. (4), which examines how the Reforms affected inventive output (patenting). The specification in column 2, that examines patent grants issued by CIPO, reveals a sizable positive estimate on the same interaction term (ReformCanada). Similar results are found when we weight the patent counts with two different measures of patent values: the number of claims and patent classes embedded in each patent (columns 3 and 4). Regressions in columns 5-9 use the USPTO and EPO patent data instead, since the CIPO patent data may be biased due to the introduction of maintenance fees (and other shifts that may change the propensity to use the new Canadian patent system). All regressions based on the USPTO data (columns 5-8) reveal a positive and large estimate on the Reform-Canada interaction, suggesting that Canadian inventors had a larger increase in USPTO patenting in the post-reform period than American inventors. In contrast, there was little difference between Canadians and Americans in their filing of EPO patent applications (despite the fact that the new Canadian patent system very much resembled the system used by EPO) as the regression in column 9 shows a small and insignificant estimate of the same interaction term.

The results in Table 2 imply that the Reforms had a positive impact on Canadian inventors' patenting both in Canada and in their largest export market (the U.S.) but no influence on their inventive efforts. Nevertheless, it is premature to put forward a case supporting the switch to a first-to-file system based on these findings. Some of the covariates in the regression may have different effects on inventive activity across countries. For example, exports have played a vital role in the Canadian economy while 
U.S. exports constitute only a small part of America's massive economy. Consequently, the degree to which exports, and hence international competition, affects inventive activity may differ for Canadians and Americans.

To address this concern, the specifications in Table 3 include in the set of covariates the interaction term between industrial exports (in natural logarithm) and the Canada dummy. All columns except column 9 report a positive estimated coefficient on the new interaction term. Not surprisingly Canadian exports were directly correlated with US patent grants awarded to Canadian inventors (columns 5 to 8). However, all the regression specifications in Table 3 reveal a small and insignificant estimate of the interaction between the Reform and the Canada dummies. The results shown in Table 3 suggest that the seemingly positive impact of the Reforms on Canadian patenting we found earlier was, in fact, driven by Canadian industrial exports, rather than the switch to the first-to-file rule. ${ }^{39}$

In addition to that the impact of exports on inventive activity varies across countries, exports may have different effects across time. The Canada-U.S. Free Trade Agreement came into force at the same time as the 1987 Patent Reform. In Table 4, we add another interaction term - between the Reform dummy and industrial exports. The positive and significant coefficient on the newly added interaction term found in column 1 suggests that industrial exports were not a significant factor in explaining R\&D efforts made by both American and Canadian inventors prior to 1987 but the importance grew larger in the post-reform years. The estimated coefficients on all other explanatory

${ }^{39}$ A closer look at Tables 3 (and 4) reveals that the coefficient on the interaction between Reform and Canada, although statistically insignificant, is negative for EPO applications as well as all weighted CIPO and USPTO patenting, except USPTO forward citations. Some may conclude from these findings that the Reforms adversely affected Canadian inventive output since the discrepancy in the results with forward citations may result from the truncation problem. See Appendix 4 for more details. 
variables are comparable to those displayed in Table 3. For example, all columns except column 9 show a positive estimated coefficient on the interaction term between industrial exports and the Canada dummy. Canadian exports were conducive to Canadian inventive activity, especially USPTO patents (and their associated value measures) awarded to Canadian inventors. Most importantly, the coefficient of the interaction term between the Reform and the Canada dummies remains statistically insignificant in all the columns. All these results suggest that any relative increase in Canada's inventive activity in the post-reform years was a result of rising exports (or greater exposure to international competition). ${ }^{40}$ The Reforms did not affect Canadian R\&D input, and the switch to a first-to-file system failed to raise patents awarded domestically (CIPO) or abroad (USPTO and EPO) to Canadian inventors.

As our findings thus far suggest that exports were an important factor in explaining patented inventions made by Canadian inventors, industries focusing on foreign markets may be less affected by the Reforms, while industries doing business largely within the domestic market may experience a large impact of the domestic patent policy shift. Regressions in Table 5 further divide the Canadian and American industries into two groups according to Canadian industrial export ratios: industries that Canadians had high export ratios (being export-oriented) and the others that Canadians had low export-ratios (being domestic-oriented). We found that in each and every regression on patenting the estimated coefficient of being domestic-oriented and Canadian industries in

${ }^{40}$ When we enter only the Export-Reform interaction term into the regressions without the ExportCanada interaction term, the estimates for the Reform-Canada interaction term remain similar to those in Table 2. We also find no serious multi-collinearity problem among these independent variables. All these suggest that the estimated coefficients on the Reform-Canada interaction term in Table 2 suffer from a positive bias, and such a bias comes from the omitted Exports-Canada interaction term. 
the post-reform years is negative though not statistically significant. ${ }^{41}$ For example, 0.114 in column 4 implies that, after the Reforms, Canadian domestic-oriented industries had $11.4 \%$ less CIPO patenting (weighted by number of classes) than Americans in the same industries or Canadian inventors in export-oriented industries. These results suggest that the Reforms may have a small negative impact on patenting by Canadian industries that were domestic-oriented, where we would expect to rely more on the domestic patent law.

\section{B. Did the Reforms Change the Ownership Structure of Patented Inventions?}

The switch to a first-to-file system may also alter the ownership structures of patented inventions. Opponents of such a patent policy shift often argue that it will hurt small entities (independent inventors and small businesses). To test this idea, we classify USPTO patents made by Canadian inventors according to their ownership structure at the time these patents were granted: not assigned, assigned to individuals, assigned to small businesses, and assigned to large corporations. ${ }^{42}$ Table 6 reports the distribution of these patents. Figure 7 plots the patent time trends by types of ownership (excluding patents assigned to individuals as they accounted for less than $2 \%$ of the total patents). Both Table 6 and Figure 7 reveal that immediately after the Reforms, Canadian small businesses witnessed a substantial decline in patenting in the U.S. In contrast, large

${ }^{41}$ The (insignificant) estimated coefficient of the Reform-Domestic-Canada interaction in column 1 is 0.176 , implying that $R \& D$ spending of Canadian domestic industries were $17.6 \%$ more than their American counterparts. However, we do not think this translates into a sizable impact on R\&D spending. In unreported regressions without the Exports-Reform interaction, the same coefficient is only 0.033 (and not statistically significant) while estimated results in columns 2-9 are comparable to those in Table 5. A multicollinearity test reveals that this coefficient change in column 1 may be due to multi-collinearity.

${ }^{42}$ A firm is classified as a large corporation if it either had access to large capital markets (being listed in major stock exchanges, such as NYSE, TSE or NASDAQ), or had more than 500 employees (the conventional classification according to U.S. Small Business Administration, 2008). (Nonetheless, in our sample very few firms with fewer than 500 employees were listed companies.) In contrast, a patent is identified as being owned by small business if it did not meet our criteria for large corporations or it was assigned to individuals. 
corporations continued to experience a moderate growth. Independent inventors (not assigned) appeared to lose ground in terms of patent ownerships to large corporations in the post-reform years as well. Large corporations’ patents accounted for a significantly smaller proportion of patents in the pre-reform years than not assigned patents, but after the Reforms the shares of patents assigned to large corporations became comparable to those of patents that were not assigned. ${ }^{43}$ The divergence between small entities and large corporations in patenting after the Reforms supports the idea that a switch to a first-to-file system will result in relatively less inventive activity being carried out by independent inventors as well as small businesses, and more being channeled through large corporations instead. ${ }^{44}$

We also examine the difference in patenting between large Canadian corporations and other types of Canadian businesses (not assigned, assigned to individuals and assigned to small businesses) with regression analysis. Table 7 reports the results. ${ }^{45}$ All columns reveal a negative and statistically significant coefficient of being a small entity and in a post-reform year. For example, -0.209 in column 1 suggests that small entities had $20.9 \%$ less USPTO patenting than large corporations after the Reforms. ${ }^{46}$ These

43 We cannot identify who sponsored CIPO patented inventions because we do not have information on assignment-at-issue. We only have information on current ownership of CIPO patents which can include secondary assignments. Nor do we have R\&D and EPO patent data at the firm level.

${ }^{44}$ Information on these firms is retrieved from www.google.com as well as ORBIS, FP Advisor, and Canadian Business Resource databases. We would prefer to collect such information around the Patent Reforms. However, these databases tend to only contain recent records (mostly after 2005). Therefore, small firms who were assigned the patents in earlier years (before the Reforms) may appear in these firm databases as large corporations today. Our classification in earlier years is therefore biased towards large corporations. The decline in patenting of small businesses after the Reforms would have been more apparent if we could obtain firm information for the late 1980s and early 1990s.

45 The estimated coefficients of the interaction between the Reform and the Small dummies can also be obtained as follows. We first determine the difference in the mean number of patents (or their weighted value) before and after the Reforms for each group. Then, calculate the difference of the difference in the means of the two groups.

${ }^{46}$ Earlier results show that exports played an important role in explaining Canadian patenting. Given the fact that the variations in (and dependency on) exports may vary across firm sizes, the estimated 
findings lend further support to the idea that a switch to the first-to-file principle benefits large corporations and puts small businesses (and independent inventors) into a disadvantageous position. ${ }^{47}$

\section{CONCLUSION}

A switch from a first-to-invent to a first-to-file patent regime may be imminent in the U.S. To understand how such a policy change may affect U.S. inventive activity, we examine a similar policy change that took place in Canada in 1989. We find that the adoption of the first-to-file rule did not induce additional R\&D efforts made by Canadian inventors. Nor did such a policy change have any effects on Canada's overall inventive output whether measured as patenting at home or abroad. In fact, international competition or exports played a more important role in explaining Canadian inventive activity. However, the new patent regime seemed to have a small adverse effect on Canadian domestic-oriented industries. The policy shift also appeared unfavorable to independent inventors and small businesses, and it channeled inventive activity towards large corporations.

The fact that Canada's adoption of a first-to-file system had virtually no positive effect on its overall inventive activity but a negative impact on its domestic-oriented

coefficient on the interaction between Reform and small entities dummies may, to some extent, also capture this difference in exports between small entities and large corporations. However, it is hard to believe that the impact from exports would be so different across firm sizes that it washed away the actual effects of the Reforms on small entities. (In fact, to our knowledge, no prior work or media coverage has suggested that export markets affected small entities and large corporations asymmetrically after the Reforms.)

${ }^{47}$ Ideally, we should compare the change in ownership structure of Canadian firms with that of U.S. firms. Unfortunately, similar information on U.S. firms is not readily available and we do not have resources to collect the information ourselves. Nonetheless, there is little reason to believe that the change in ownership structure of these patented inventions by Canadians came from other factors than the Reforms. (The decrease in small business assignments came in 1990, and none of the prior literature and policy discussion suggests probable policy shifts which would lead to such a drastic change in the distribution of firm size towards large firms during the period of our investigation.) 
industries as well as independent inventors and small firms challenges the merits of the proposed 2007 U.S. Patent Reform Act. The U.S. relies even more heavily on its domestic markets than Canada. In addition, as independent inventors and small firms rarely have comparable resources to compete with large corporations in the race to the Patent Office, a switch to a first to file system contradicts the very essence of the longstanding U.S. patent laws: making patent protection equally accessible to anybody. ${ }^{48}$ More importantly, independent inventors and small firms have played an important role in the U.S. technological leadership since its independence. Salient examples of those who have helped in the U.S. achievement are Thomas A. Edison, Bill Gates, Yahoo and Google, Inc. It is therefore crucial to provide an unbiased legal environment for invention and innovation, which helps these independent inventors and small firms to prosper, and the first-to-invent rule apparently serves such a purpose better than its first-to-file counterpart. $^{49}$

${ }^{48}$ Kahn (2005) discusses how supportive the U.S. Patent System was to small entities and how this may help the U.S. accomplish it technological achievement.

${ }^{49}$ A caveat for the findings from this paper is that the analysis does not touch on other potential (social) benefits of such a switch. For example, a first-to-file system may reduce litigation costs in determining who has the right to an invention if multiple patent applications are filed on that invention. Such a system also creates new market opportunities to trade patent applications, as they are laid open once submitted to the patent office. In addition, there may be some positive externalities from coordinating patent systems around the world. 


\section{APPENDiX 1. How the INTRODUCTION OF RENEWAL FEES MAY BiAs OUR DifFERENCE-IN- DIFFERENCE COMPARISON}

The following example illustrates how the introduction of renewal fees by CIPO after the Reforms may be an issue for our analysis (Figure A1). Suppose the CIPO patent values of both Canadians and Americans are normally distributed. However, American patents, on average, are of higher value than Canadian ones. The maintenance fees shift the cost of patenting from a (a one-time application fee) to b (a one-time application fee and annual maintenance fees on application), where $\mathrm{b}>\mathrm{a}$. The difference-in-difference coefficient (interactions of the Reform dummy with Canada) provides the estimator: B minus A. The introduction of maintenance fees leads the difference-in-difference approach to yield a negative estimate of the value, B minus A, even with no change in inventive activity of both Americans and Canadians. Apparently, as long as the average value or quality of inventions created by Canadian inventors is different from the average value of inventions made by Americans, a non-zero estimate likely occurs with a change increase in patenting cost even if there is no change in inventive activity in both countries.

\section{APPENDiX 2. PATENT AND INDUSTRY CLASSIFICATION SySTEMS}

Both CIPO and USPTO patents are classified based on their functional use rather than the conventional industrial classification. In order to perform analysis at the industry level, it is necessary to allocate each patent according to its industry of manufacturing. One way of doing so is to manually assign patents according to industry classification. However, this is an insurmountable task given the number of patents needed to be examined. Alternatively, we can utilize a patent-industry concordance system that assigns a probability associated with each patent class and each industry class, and maps a patent 
count for each patent class into a patent count for each industry class. For example, if a probability that a patent awarded in class A is made by industry B is 0.2 and if there are 100 patents awarded in class A, then such a concordance system will yield 20 patents made by industry $B$.

There are two patent-industry concordance systems: Yale Technology Concordance (YTC) and Silverman's International Patent Classification-U.S. SIC Concordance. The two systems are quite similar and were actually developed from the CIPO data. (See Evenson and Johnson, 1997 for YTC, and Silverman, 1996 for Silverman's Concordance.) Nevertheless, there are a few notable differences between the two systems. The YTC is a basis for the newer OECD Technology Concordance (OTC), and was developed using the CIPO patent grants data during 1983 and 1993. As a result, the YTC generally makes large errors in predicting patents by industry after 1989 (Kortum and Putnam, 1997). In contrast, Silverman’s Concordance utilizes CIPO patent grants during 1990 and 1993 which leads to smaller errors in later years. Some manufacturing sectors (for example, shoe and leather, printing, and furniture industries) are missing from the YTC output matrix. As a result, we use Silverman's Concordance to transform our patent count data into industries. Our results change very little even if we use the YTC.

Silverman's Concordance (Silverman, n.d.) provides a conversion from the International Patent Classification (IPC) to the U.S. Standard Industrial Classification (U.S. SIC). Since CIPO adopts the IPC, we can transform the CIPO patent data into U.S. SIC directly. On the other hand, the USPTO data that we use classifies patents according to the U.S. Patent Classification (USPC). Therefore, we utilize another concordance 
system - Wellesley Technology Concordance (WTC) - that converts USPC to IPC, before we apply Silverman’s Concordance to the USPTO data (Johnson, n.d.).

Finally, in order for our industry patent counts to conform to other data (for example, R\&D, exports and producer price index), we further group the SIC into 17 industries listed in Table A1 in Appendix 3.

\section{APPENDIX 3. CHARACTERISTICS OF INDUSTRIES}

Table A1 reports R\&D spending, number of CIPO and USPTO patent grants and claims, as well as export and production values of Canadian manufacturing industries in 1989. Based on the ratio between their export and production values, we then identify domestic- and export-oriented industries. (Some industries had their export ratios well above 1 . This is perhaps attributable to the fact that production values are value-added figures, while export values include values of imported contents.)

\section{Appendix 4. Truncation Problem in Patent Citation Data}

There is a right truncation in forward citation data. A patent may be cited by subsequent patents as prior art. A patent filed (and granted) in the distant past has a longer time span of exposure to be cited by later patents than a patent that was filed recently. We deal with this problem by fixing the duration of exposure to citation to four years. That is, we only include citing patents filed within four years after the cited patent was granted, and hence made public. We have such a short fixed widow because the information on forward citation is only available for patents granted in and before 2002 . Since it normally takes USPTO about 2 to 3 years to award a patent, a patent filed in 
1994 was likely granted after 1996, and a patent granted in 2002 was likely filed before

2000. Thus, the window of exposure for a patent filed in 1994 is only 4 years long.

However, even with the use of a fixed window of citation exposure (and the inclusion of year dummies in the regressions), the truncation problem in forward citations may still be too severe and cannot be fully corrected for our analysis. As shown in Figure A2, when the window is fixed, the fall in forward citations still persisted (but was delayed till 1992), while the average backward citations rose over time.

\section{REFERENCES}

Bartelsman, Eric J., Randy A. Becker, and Wayne B. Gray. "The NBER-CES Manufacturing Industry Database,” June 2000. Retrieved June, 2008, from http://www.nber.org/nberces/nbprod96.htm.

Canadian Intellectual Property Office. Annual Reports (1995-2000). Retrieved August 1, 2008, from http://strategis.ic.gc.ca/sc_mrksv/cipo/corp/allreport-e.html. . "Canadian Patents Database." Retrieved January-August, 2008, from http://patents.ic.gc.ca/cipo/cpd/en/introduction.html.

Canadian Business Resource. Canadian Newspaper Services International Limited. Retrieved May-August 2008, from http://www.cbr.ca.

Debari, Vito J. "International Harmonization of Patent Law: A Proposed Solution to the United States’ First-to-File Debate.” Fordham International Law Journal, Vol. 16 (1993), pp. 687-720.

Duy, Vic. "A Brief History of the Canadian Patent System." The Canadian Biotechnology Advisory Committee Research Paper (January 2001).

Erickson, Scott. "Patent Law and New Product Development: Does Priority Claim Basis Make a Difference?” American Business Law Journal, Vol. 36, No. 2 (Winter 1999), pp. 327-347.

Evenson, Robert E., and Daniel K. N. Johnson. "Introduction: Invention Input-Output Analysis.” Economic Systems Research, Vol. 9, No. 2 (June 1997), pp.149-160.

FP Advisor. "Company Snapshot Search.” CanWest Mediaworks. Retrieved May-August 2008, from http://www.fpinfomart.ca.

Frost, George E. "The 1967 Patent Law Debate: First-to-Invent vs. First-to-File.” Duke Law Journal, Vol. 1967, No. 5, (October 1967), pp. 923-942.

Gallini, Nancy, Jonathan Putnam, and Andrew Tepperman. "Intellectual Property Rights and the Propensity to Patent." In Intellectual Property Rights and Innovation in the Knowledge-Based Economy," Jonathan Putnam (ed). Ottawa: Industry Canada, 2006. 
Goss, Grant. "Patent Reform Bill Progresses.” PC World (March 14, 2008). Retrieved August 11, 2008, from http://www.pcworld.com/article/143448/patent_reform_bill_progresses.html.

Hall, Brownwyn H. “2002 Updates to NBER Patent Data.” Retrieved March 2008, from http://elsa.berkeley.edu/ bhhall/bhdata.html.

Hall, Brownwyn H., Adam B. Jaffe, and Manuel Trajtenberg. "The NBER Patent Citation Data File: Lessons, Insights and Methodological Tools.” NBER Working Paper 8498, 2001.

. “The NBER U.S. Patent Citations Data Files.” Retrieved March 2008, from http://www.nber.org/patents.

Hall, Bronwyn H., and Rosemarie Ham Ziedonis. "The Patent Paradox Revisited: An Empirical Study of Patenting in the U.S. Semiconductor Industry, 1979-1995.” The RAND Journal of Economics, Vol. 32, No. 1 (Spring 2001), pp. 101-128.

Harbers, Michael J. "International Patent Cooperation.” Stanford Law Review, Vol. 20, No. 5 (May 1968), pp. 1000-1029.

H.R. 1908 and S. 1145, 110th Cong. (2007).

Johnson, Daniel K. N. “The Wellesley Technology Concordance (WTC).” Retrieved June 2008, from http://faculty1.coloradocollege.edu/ djohnson/uships.html.

Johnson, Daniel K. N., and David Popp. "Forced out of the Closet: The Impact of the American Inventors Protection Act on the Timing of Patent Disclosure." The Rand Journal of Economics, Vol. 34, No. 1 (Spring 2003), pp. 96-112.

Jordan, Michael C. “The Politics of Drug Patenting in Canada, 1965-2005.” MA Thesis, University of Saskatchewan (2005).

Khan, B. Zorina. The Democratization of Invention: Patents and Copyrights in American Economic Development, 1790-1920. New York, NY: Cambridge University Press (2005).

Kortum, Samuel, and Josh Lerner. "What is Behind the Recent Surge in Patenting?" Research Policy, Vol. 28, No.1 (January 1999), pp. 1-22.

Kortum, Samuel, and Jonathan Putnam. "Assigning Patents to Industries: Tests of the Yale Technology Concordance.” Economic Systems Research, Vol. 9, No.2 (June 1997), pp. 161-175.

Lerner, Josh. "The Importance of Patent Scope: An Empirical Analysis." The Rand Journal of Economics, Vol. 25, No. 2 (Summer 1994), pp. 319-333.

Lanjouw, Jean O., and Mark Schankermann. "Patent Quality and Research Productivity: Measuring Innovation with Multiple Indicators.” Economic Journal, Vol. 114 (April 2004), pp. 441-465.

Lo, Shih-tse. "Strengthening Intellectual Property Rights: Experience from the 1986 Taiwanese Patent Reforms.” Mimeo (June 2008).

Martin, Michael F. “A History of the First-to-Invent Rule of Priority in United States Patent Law.” Mimeo (May 2006).

Meredith, John, and Keith Grzelak. "Letter to House and Senate Leaders and Judiciary Committee Members Opposing Adoption of the Patent Reform Act of 2007 (S. 1145/H.R. 1908).” The Institute of Electrical and Electronics Engineers, Inc. United States of America (August 27, 2007). Retrieved August 15, 2008, from http://ieeeusa.org/policy/POLICY/2007/082707.pdf.

Merges, Robert P. Patent Law and Policy. Charlottesville: Michie Company, 1992. 
Meyer, Bruce D. "Natural and Quasi- Experiments in Economics.” Journal of Business \& Economic Statistics, Vol. 13, No. 2 (April 1995), pp. 151-162.

Miyagiwa, Kaz. "First-to-Invent Versus First-to-File: International Patent Law Harmonization and Innovation.” ISER Discussion Paper No. 703 (November 2007).

Moser, Petra. "How do Patent Laws Influence Innovation? Evidence from NineteenthCentury World Fairs.” American Economic Review, Vol. 95, No. 4 (December 2005), pp. 1215-1236.

Organization for Economic Co-Operation and Development. Basic Science and Technology Statistics. Paris, France: OECD Publications Service (1999). . “OECD.StatExtracts.” Retrieved October 4, 2008 from http://webnet.oecd.org/wbos/.

ORBIS. Bureau van Dijk Electronic Publishing. Retrieved May-August 2008, from https://orbis.bvdep.com.

Pakes, Ariel, and Zvi Griliches. "Patents and R\&D at the Firm Level: A First Report." Economics Letters, Vol. 5, No. 4 (1980), pp. 377-381.

. "Patents and R\&D at the Firm Level: A First Look." In R\&D, Patents and Productivity, Zvi Griliches (ed.), Chicago: University of Chicago Press, 1984.

Patent Reform Act of 1967, S. 1691 and H.R. 5924, 90th Cong. (1967).

Patent Reform Act of 2005, H.R. 2795, 109th Cong. (2005).

Patent Reform Act of 2007, H.R. 1908 and S. 1145, 110th Cong. (2007).

Patent System Harmonization Act of 1992, S. 2605 and H.R. 4978, 102 Cong. (1992).

Sakakibara, Mariko, and Lee Branstetter. "Do Stronger Patents Induce More Innovation? Evidence from the 1998 Japanese Patent Law Reforms.” The Rand Journal of Economics, Vol. 32, No. 1 (Spring 2001), pp. 77-100.

Scotchmer, Suzanne. "On the Optimality of the Patent Renewal System." The Rand Journal of Economics, Vol. 30, No. 2 (Summer 1999), pp. 181-196

Scotchmer, Suzanne, and Jerry Green. "Novelty and Disclosure in Patent Law." The Rand Journal of Economics, Vol. 21, No. 1 (Spring 1990), pp. 131-146.

Sekiguchi, Waichi. "U.S. is Pressured to Change System of Patent Protection." The Globe and Mail, December 27, 1989. Retrieved September 10, 2008, from http://www.lexisnexis.com.

Silverman, Brian S. "Technological Assets and the Logic of Corporate Diversification.” PhD diss., University of California at Berkeley, Haas School of Business (1996).

"Documentation for International Patent Classification - U.S. SIC Concordance.” Retrieved June 2008, from

http://www.rotman.utoronto.ca/ silverman/ipcsic/documentation_IPC-

SIC_concordance.htm.

Statistics Canada. “CANSIM.” Retrieved June 2008, from http://cansim2.statcan.ca. . Industrial Research and Development. Ottawa, Canada: Government of Canada (1988-1997).

Trajtenberg, Manuel. “A Penny for Your Quotes: Patent Citations and the Value of Innovations.” The Rand Journal of Economics, Vol. 21, No. 1 (Spring 1990), pp. 172-187. 
."R\&D Policy in Israel: An Overview and Reassessment". In Maryann P. Feldman and Albert N. Link (eds.), Innovation Policy in the Knowledge-Based Economy. Boston: Kluwer Academic Publishers, 2001, pp. 409-454.

."Is Canada Missing the 'Technology Boat'? Evidence from Patent Data". In Someshwar Rao and Andrew Sharpe (eds.), Productivity Issues in Canada. University of Calgary Press, 2002, pp. 245-280. Forthcoming also in Pierre Fortin and Craig Riddell (eds.), Growth, Employment and Technology: New Perspectives on Canadian Policies. McGill-Queen's University Press.

Trajtenberg, Manuel, Rebecca Henderson, and Adam B. Jaffe. "University versus Corporate Patents: A Window on the Basicness of Invention." Economics of Innovation and New Technology, Vol. 5, No. 1 (1997), pp. 19-50.

Trefler, Daniel. "The Long and Short of the Canada-U.S. Free Trade Agreement." American Economic Review, Vol. 94, No. 4 (September 2004), pp. 870-895.

United Nation. “Commodity Trade Statistics Database.” Retrieved June, 2008, from http://comtrade.un.org/db/default.aspx.

U.S. Congressional Record. Various Volumes.

U.S. International Trade Commission. "Interactive Tariff and Trade Dataweb.” Retrieved September 17, 2008, from http://dataweb.usitc.gov.

U.S. National Science Foundation. Research and Development in Industry (1990 and 1995). Retrieved June 2008, from http://www.nsf.gov/statistics/industry.

U.S. Patent and Trademark Office. "USPTO FY 2008 Fee Schedule.” Retrieved July, 2008, from http://patft.uspto.gov.

. “USPTO Patent Full-Text and Image Database.” Retrieved March-August, 2008, from http://patft.uspto.gov.

U.S. Small Business Administration. "Table of Small Business Size Standards Matched to North American Industry Classification System Codes,” 2008. Retrieved August 1, 2008, from

http://www.sba.gov/idc/groups/public/documents/sba_homepage/serv_sstd_tablep df.pdf.

White, Michael. “Canadian Patent Number Guide.” Pamphlet, Queen’s University Engineering and Science Library (January 2008). Retrieved August 7, 2008, from http://library.queensu.ca/webeng/patents/Canadian_Patent_Number_Guide.pdf.

Wiggs, Blake R. “Canada's First-to-File Experience - Should the U.S. Make the Move?” Journal of the Patent and Trademark Office Society, Vol. 73, No.7 (July 1991), pp. 493-513.

Wilkinson, Bruce W. “Free Trade.” The Canadian Encyclopedia. Historica Foundation of Canada. Retrieved August 1, 2008, from http://www.thecanadianencyclopedia.com.

World Trade Organization. "Compulsory licensing of pharmaceuticals and TRIPS." Retrieved August 11, 2008, from http://www.wto.org/english/tratop_e/TRIPs_e/public_health_faq_e.htm. 
TABLE 1

Annual Statistics of Selected Measures of Inventive Activity Carried out by Canadians and Americans

\begin{tabular}{|c|c|c|c|c|c|c|c|c|c|c|c|c|c|c|c|c|}
\hline Year & 1980 & 1981 & 1982 & 1983 & 1984 & 1985 & 1986 & 1987 & 1988 & 1989 & 1990 & 1991 & 1992 & 1993 & 1994 & 1995 \\
\hline \multicolumn{17}{|c|}{ Panel A: Canadians } \\
\hline CIPO applications & 1,785 & 1,951 & 1,936 & 2,017 & 2,026 & 2,092 & 2,161 & 2,527 & 2,772 & 3,031 & 2,564 & 2,433 & 2,628 & 2,791 & 2,926 & 2,957 \\
\hline CIPO grants & 1,348 & 1,474 & 1,446 & 1,485 & 1,444 & 1,428 & 1,369 & 1,511 & 1,639 & 1,625 & 1,009 & 984 & 1,058 & 1,123 & 1,216 & 1,229 \\
\hline CIPO claims & & & & 19,302 & 19,625 & 19,070 & 19,374 & 22,132 & 24,497 & 23,617 & 15,615 & 15,455 & 17,410 & 18,815 & 20,504 & \\
\hline CIPO IPC classes & 3,387 & 4,075 & 3,745 & 3,812 & 3,859 & 3,717 & 3,703 & 4,135 & 4,425 & 4,518 & 3,080 & 3,058 & 3,612 & 3,822 & 3,987 & 3,765 \\
\hline USPTO grants & 1,124 & 1,160 & 1,109 & 1,091 & 1,294 & 1,300 & 1,402 & 1,672 & 1,884 & 2,037 & 1,940 & 2,062 & 1,998 & 2,313 & 2,565 & 3,065 \\
\hline USPTO claims (thousand) & 12 & 13 & 12 & 13 & 15 & 15 & 17 & 21 & 24 & 26 & 26 & 27 & 28 & 31 & 36 & 46 \\
\hline EPO applications & 155 & 193 & 258 & 319 & 368 & 383 & 403 & 452 & 552 & 553 & 637 & 516 & 585 & 578 & 650 & 737 \\
\hline Real R\&D (million CAD) & 2,118 & 2,587 & 2,855 & 2,960 & 3,171 & 3,560 & 3,608 & 3,798 & 3,875 & 3,840 & 4,074 & 4,278 & 4,299 & 4,642 & 4,767 & 5,009 \\
\hline \multicolumn{17}{|c|}{ Panel B: Americans } \\
\hline CIPO applications & & & & & 13,028 & 13,128 & 13,013 & 13,426 & 14,687 & 16,806 & 15,020 & 15,058 & 14,630 & 14,174 & 14,814 & 14,986 \\
\hline CIPO grants & 861 & 935 & 814 & 826 & 750 & 860 & 791 & 784 & 841 & 795 & 486 & 519 & 507 & 503 & 586 & 539 \\
\hline CIPO claims & & & & 12,336 & 11,455 & 14,679 & 13,672 & 14,609 & 14,585 & 15,065 & 9,407 & 10,862 & 10,118 & 10,509 & 12,012 & \\
\hline CIPO IPC classes & 2,382 & 2,652 & 2,290 & 2,393 & 2,188 & 2,704 & 2,521 & 2,519 & 2,814 & 2,864 & 1,861 & 1,958 & 2,081 & 1,948 & 2,400 & 2,115 \\
\hline USPTO grants & 38,953 & 36,843 & 36,603 & 34,507 & 36,275 & 37,731 & 38,945 & 42,473 & 47,037 & 50,292 & 53,359 & 54,069 & 57,315 & 60,626 & 67,989 & 81,187 \\
\hline USPTO claims (thousand) & 435 & 417 & 423 & 419 & 450 & 483 & 514 & 579 & 649 & 714 & 769 & 778 & 843 & 921 & 1,069 & 1,336 \\
\hline EPO applications & 5,247 & 6,482 & 7,485 & 9,098 & 10,193 & 10,757 & 11,690 & 12,110 & 13,461 & 15,019 & 17,142 & 16,883 & 17,621 & 17,734 & 18,408 & 19,560 \\
\hline Real R\&D (million USD) & 35,227 & 37,628 & 41,496 & 45,631 & 51,329 & 52,691 & 56,320 & 56,259 & 57,136 & 58,269 & 58,617 & 60,517 & 63,415 & 62,213 & 65,277 & 72,895 \\
\hline
\end{tabular}

Notes: The annual statistics of CIPO patent grants, claims and classes are from CIPO's Canadian Patents Database. The annual number of CIPO patent applications is from OECD (1999) for 1980-1989 and from CIPO's Canadian Patents Database for 1990-1995. The CIPO Canadian Patents Database only provides application statistics after October 1, 1989. There are large discrepancies in application statistics between OECD and the Canadian Patents Database during 1990-1995. We rely on the Canadian Patents Database figures for those years. The number of patent applications, grants, claims and IPC classes include non-manufacturing industries, whereas that of real R\&D only reflects manufacturing industries. The CIPO patent data for Americans reported here is from our random sample. We do not make an extrapolation, and hence they are not in actual annual figures. The base year for real R\&D calculation is 1992 for Canada and 1987 for the U.S. 


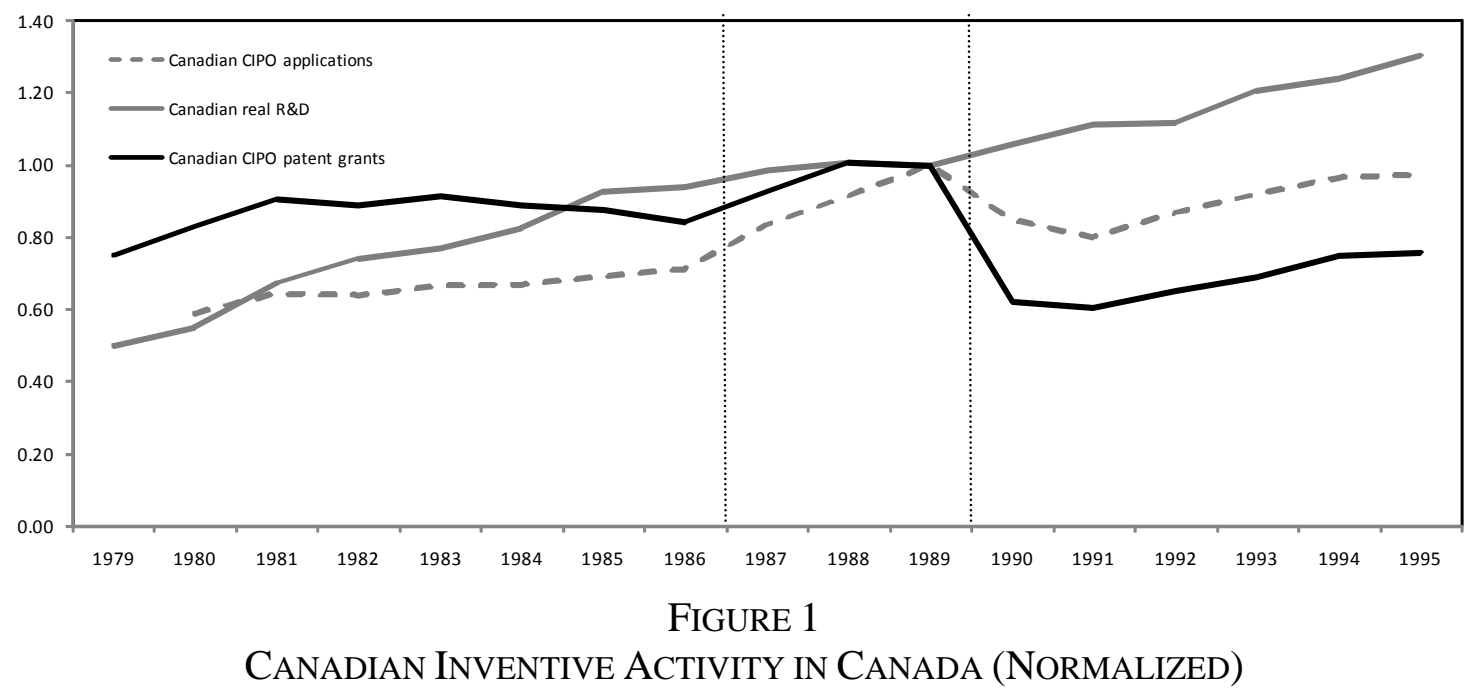

Notes: See Table 1.

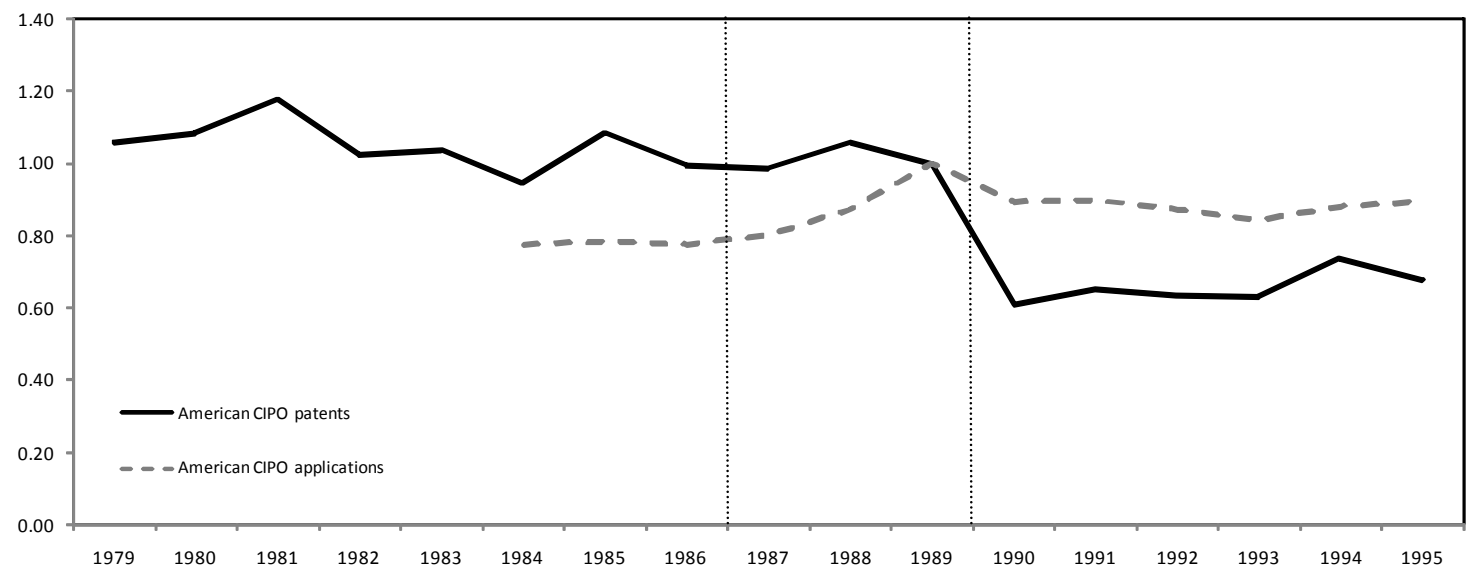

FIGURE 2

AMERICAN PATENTING In CANADA By YEAR OF APPLICATION (NoRMALIZED)

Notes: See Table 1. 


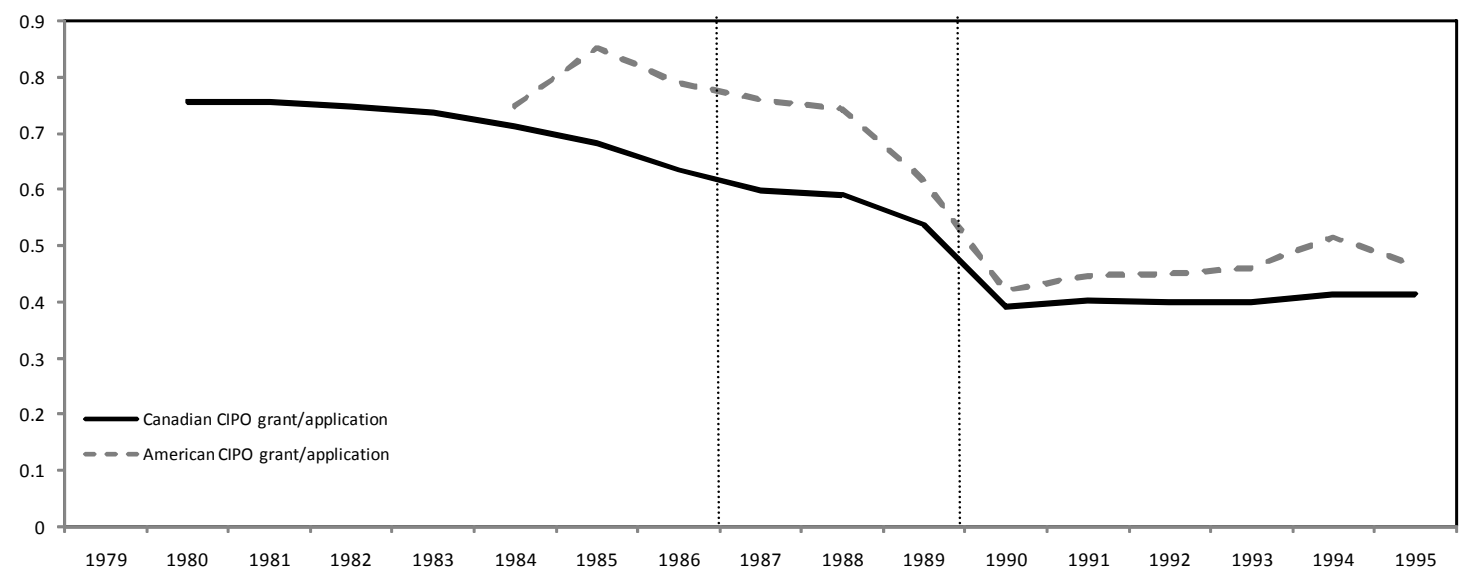

FIGURE 3

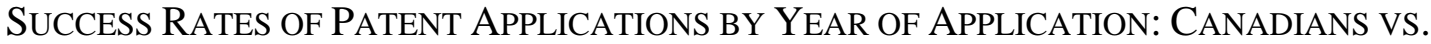
AMERICANS

Notes: These figures are calculated based on the ratio between the annual number of patent grants by year of filing and the annual number of patent applications. The annual American CIPO grant per application is estimated from the number of CIPO grants to Americans in our random sample times 13, and then divided by the number of CIPO applications by Americans.

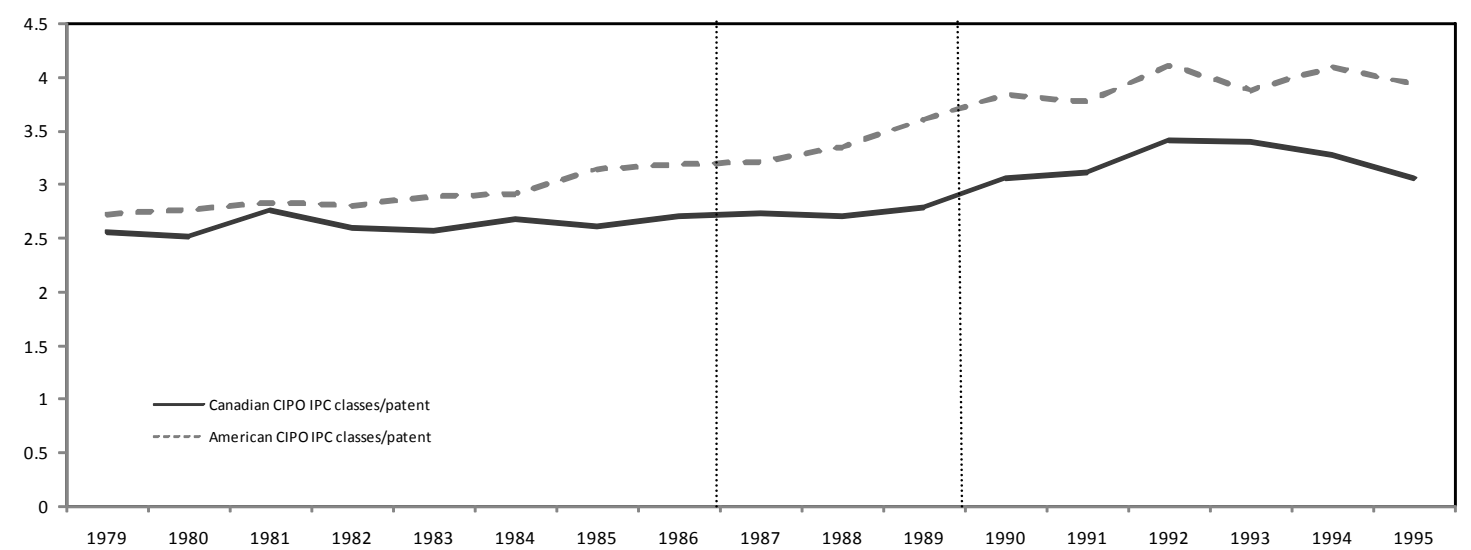

FIGURE 4

Average Values of CiPO Patents: Canadian vs. American Patents 


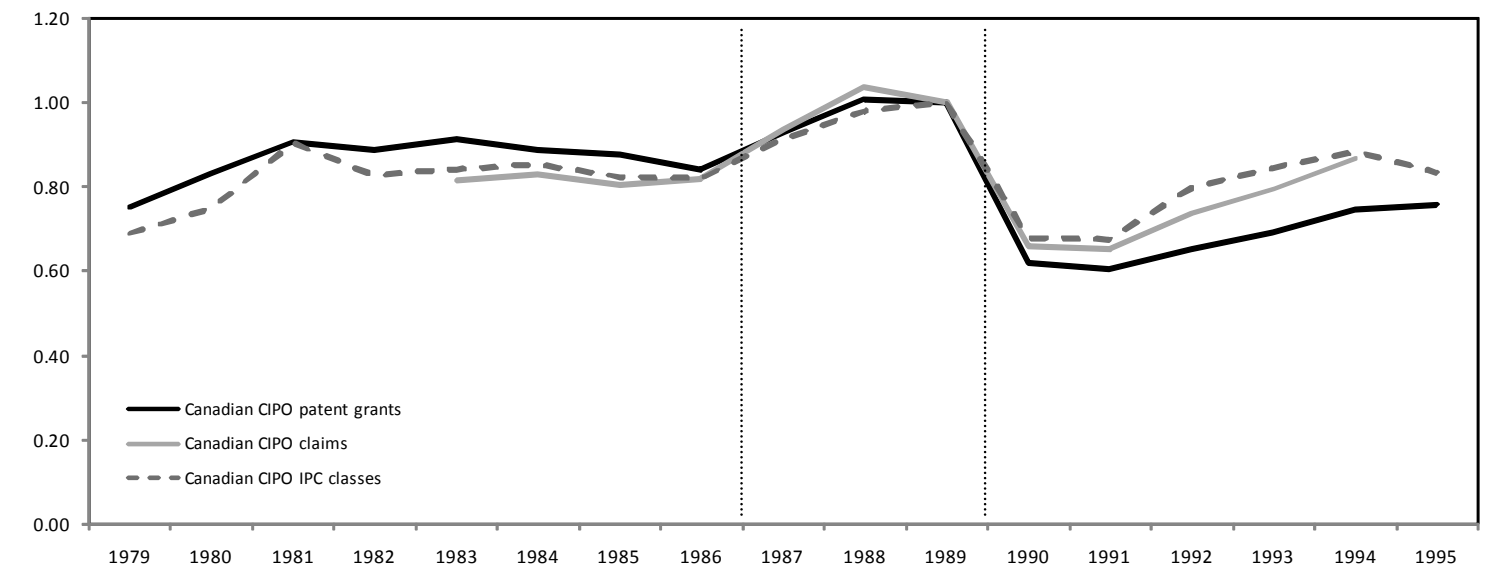

FIGURE 5

Canadian PAtenting in CANAdA By Year of ApPlication (NoRMalized, With Value WEIGHTS)

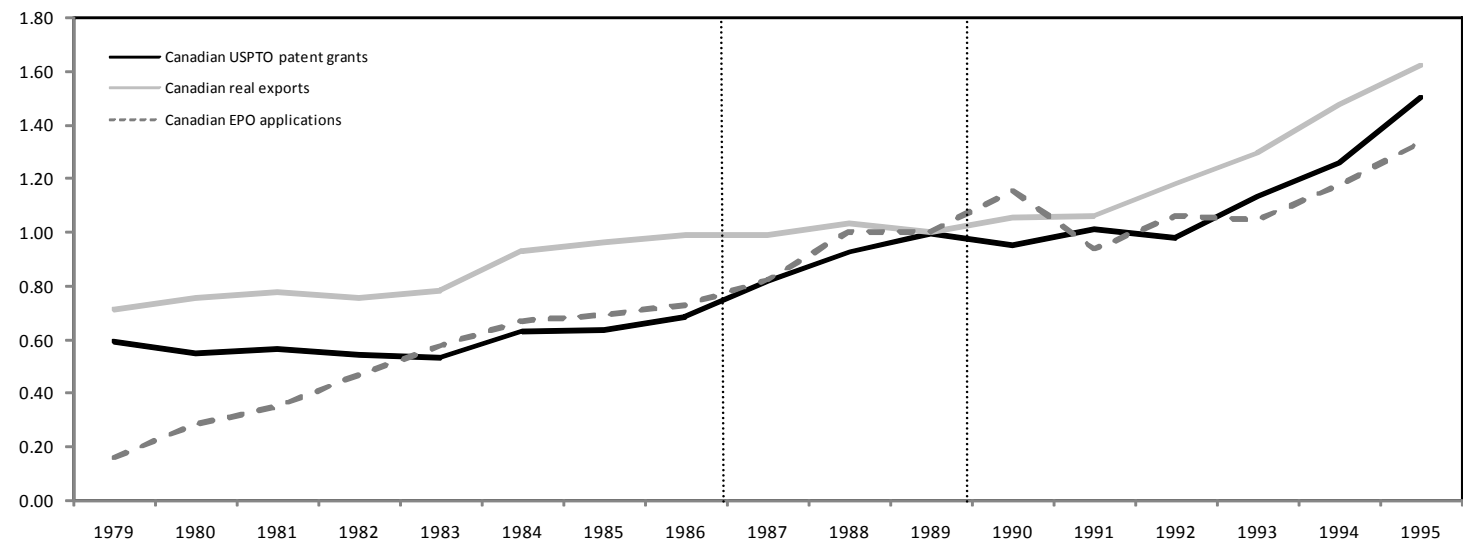

FIGURE 6

CANADIAN PATENTING IN THE U.S. AND EUROPE (NORMALIZED)

Notes: The number of USPTO patent grants and EPO patent applications include nonmanufacturing industries, whereas real exports are only for manufacturing industries. 
TABLE 2

\section{Canadian Inventive Activity as Compared to that of Americans with Industry Fixed Effects: Base Model}

\begin{tabular}{|c|c|c|c|c|c|c|c|c|c|}
\hline & (1) & (2) & $\begin{array}{c}\text { (3) } \\
\text { (CIPO paten }\end{array}$ & (4) & (5) & $\begin{array}{l}6) \\
\ln \text { (USP }\end{array}$ & $\begin{array}{r}\text { (7) } \\
\text { Opatents) }\end{array}$ & (8) & (9) \\
\hline & ln (real R\&D) & Unweighted & $\begin{array}{c}\text { Claims } \\
\text { weighted }\end{array}$ & $\begin{array}{c}\text { Classes } \\
\text { weighted }\end{array}$ & Unweighted & $\begin{array}{c}\text { Claims } \\
\text { weighted }\end{array}$ & $\begin{array}{c}\text { Backward } \\
\text { citations } \\
\text { weighted } \\
\end{array}$ & $\begin{array}{c}\text { Forward } \\
\text { citation } \\
\text { weighted } \\
\end{array}$ & $\begin{array}{c}\ln (\mathrm{EPO} \\
\text { applications) } \\
\text { unweighted }\end{array}$ \\
\hline Constant & $\begin{array}{l}-1.024 \\
(0.70)\end{array}$ & $\begin{array}{l}0.438 \\
(0.26)\end{array}$ & $\begin{array}{c}3.537 \\
(1.69)^{*}\end{array}$ & $\begin{array}{c}3.341 \\
(1.94)^{*}\end{array}$ & $\begin{array}{c}2.057 \\
(2.17)^{* *}\end{array}$ & $\begin{array}{c}5.201 \\
(4.75)^{* * *}\end{array}$ & $\begin{array}{c}5.078 \\
(4.04)^{* * *}\end{array}$ & $\begin{array}{l}0.171 \\
(0.12)\end{array}$ & $\begin{array}{l}2.604 \\
(1.59)\end{array}$ \\
\hline Year 1984 & $\begin{array}{l}0.063 \\
(1.15)\end{array}$ & $\begin{array}{l}-0.072 \\
(1.11)\end{array}$ & $\begin{array}{l}-0.057 \\
(0.72)\end{array}$ & $\begin{array}{l}-0.090 \\
(1.40)\end{array}$ & $\begin{array}{c}0.095 \\
(2.66)^{* * *}\end{array}$ & $\begin{array}{c}0.128 \\
(3.10)^{* * *}\end{array}$ & $\begin{array}{c}0.176 \\
(3.72)^{* * *}\end{array}$ & $\begin{array}{c}0.169 \\
(3.28)^{* * *}\end{array}$ & $\begin{array}{l}0.050 \\
(0.81)\end{array}$ \\
\hline Year 1985 & $\begin{array}{c}0.140 \\
(2.53)^{* *}\end{array}$ & $\begin{array}{l}-0.007 \\
(0.11)\end{array}$ & $\begin{array}{l}0.047 \\
(0.59)\end{array}$ & $\begin{array}{l}-0.015 \\
(0.22)\end{array}$ & $\begin{array}{c}0.092 \\
(2.51)^{* *}\end{array}$ & $\begin{array}{c}0.147 \\
(3.49)^{* * *}\end{array}$ & $\begin{array}{c}0.152 \\
(3.14)^{* * *}\end{array}$ & $\begin{array}{c}0.183 \\
(3.48)^{* * *}\end{array}$ & $\begin{array}{l}0.081 \\
(1.28)\end{array}$ \\
\hline Year 1986 & $\begin{array}{c}0.165 \\
(2.82)^{* * *}\end{array}$ & $\begin{array}{l}-0.105 \\
(1.50)\end{array}$ & $\begin{array}{l}-0.022 \\
(0.26)\end{array}$ & $\begin{array}{l}-0.046 \\
(0.65)\end{array}$ & $\begin{array}{c}0.160 \\
(4.11)^{* * *}\end{array}$ & $\begin{array}{c}0.254 \\
(5.66)^{* * *}\end{array}$ & $\begin{array}{c}0.270 \\
(5.24)^{* * *}\end{array}$ & $\begin{array}{c}0.247 \\
(4.42)^{* * *}\end{array}$ & $\begin{array}{c}0.226 \\
(3.36)^{* * *}\end{array}$ \\
\hline Year 1990 & $\begin{array}{l}0.073 \\
(0.86)\end{array}$ & $\begin{array}{c}-0.665 \\
(6.63)^{* * *}\end{array}$ & $\begin{array}{c}-0.352 \\
(2.87)^{* * *}\end{array}$ & $\begin{array}{c}-0.370 \\
(3.66)^{* * *}\end{array}$ & $\begin{array}{c}0.309 \\
(5.55)^{* * *}\end{array}$ & $\begin{array}{c}0.513 \\
(7.97)^{* * *}\end{array}$ & $\begin{array}{c}0.561 \\
(7.60)^{* * *}\end{array}$ & $\begin{array}{c}0.494 \\
(6.15)^{* * *}\end{array}$ & $\begin{array}{c}0.516 \\
(5.35)^{* * *}\end{array}$ \\
\hline Year 1991 & $\begin{array}{l}0.105 \\
(1.19)\end{array}$ & $\begin{array}{c}-0.804 \\
(7.82)^{* * *}\end{array}$ & $\begin{array}{c}-0.426 \\
(3.38)^{* * *}\end{array}$ & $\begin{array}{c}-0.473 \\
(4.57)^{* * *}\end{array}$ & $\begin{array}{c}0.317 \\
(5.55)^{* * *}\end{array}$ & $\begin{array}{c}0.506 \\
(7.66)^{* * *}\end{array}$ & $\begin{array}{c}0.637 \\
(8.41)^{* * *}\end{array}$ & $\begin{array}{c}0.596 \\
(7.23)^{* * *}\end{array}$ & $\begin{array}{c}0.421 \\
(4.25)^{* * *}\end{array}$ \\
\hline Year 1992 & $\begin{array}{l}0.111 \\
(1.21)\end{array}$ & $\begin{array}{c}-0.788 \\
(7.31)^{* * *}\end{array}$ & $\begin{array}{c}-0.400 \\
(3.02)^{* * *}\end{array}$ & $\begin{array}{c}-0.393 \\
(3.62)^{* * *}\end{array}$ & $\begin{array}{c}0.273 \\
(4.56)^{* * *}\end{array}$ & $\begin{array}{c}0.502 \\
(7.25)^{* * *}\end{array}$ & $\begin{array}{c}0.617 \\
(7.77)^{* * *}\end{array}$ & $\begin{array}{c}0.570 \\
(6.59)^{* * *}\end{array}$ & $\begin{array}{c}0.488 \\
(4.71)^{* * *}\end{array}$ \\
\hline Year 1993 & $\begin{array}{l}0.155 \\
(1.60)\end{array}$ & $\begin{array}{c}-0.690 \\
(6.05)^{* * *}\end{array}$ & $\begin{array}{l}-0.250 \\
(1.79)^{*}\end{array}$ & $\begin{array}{c}-0.270 \\
(2.36)^{* *}\end{array}$ & $\begin{array}{c}0.349 \\
(5.52)^{* * *}\end{array}$ & $\begin{array}{c}0.571 \\
(7.81)^{* * *}\end{array}$ & $\begin{array}{c}0.792 \\
(9.44)^{* * *}\end{array}$ & $\begin{array}{c}0.634 \\
(6.94)^{* * *}\end{array}$ & $\begin{array}{c}0.403 \\
(3.68)^{* * *}\end{array}$ \\
\hline Year 1994 & $\begin{array}{l}0.102 \\
(0.95)\end{array}$ & $\begin{array}{c}-0.634 \\
(5.02)^{* * *}\end{array}$ & $\begin{array}{l}-0.284 \\
(1.84)^{*}\end{array}$ & $\begin{array}{l}-0.221 \\
(1.74)^{*}\end{array}$ & $\begin{array}{c}0.438 \\
(6.25)^{* * *}\end{array}$ & $\begin{array}{c}0.713 \\
(8.81)^{* * *}\end{array}$ & $\begin{array}{c}0.929 \\
(10.00)^{* * *}\end{array}$ & $\begin{array}{c}0.648 \\
(6.41)^{* * *}\end{array}$ & $\begin{array}{c}0.455 \\
(3.75)^{* * *}\end{array}$ \\
\hline Reform x Canada & $\begin{array}{l}0.069 \\
(1.19)\end{array}$ & $\begin{array}{c}0.235 \\
(3.47)^{* * *}\end{array}$ & $\begin{array}{l}0.083 \\
(1.00)\end{array}$ & $\begin{array}{c}0.132 \\
(1.93)^{*}\end{array}$ & $\begin{array}{c}0.130 \\
(3.46)^{* * *}\end{array}$ & $\begin{array}{c}0.106 \\
(2.43)^{* * *}\end{array}$ & $\begin{array}{l}0.062 \\
(1.24)\end{array}$ & $\begin{array}{c}0.182 \\
(3.34)^{* * *}\end{array}$ & $\begin{array}{l}-0.068 \\
(1.05)\end{array}$ \\
\hline $\ln$ (real export) & $\begin{array}{l}0.066 \\
(0.81)\end{array}$ & $\begin{array}{c}0.249 \\
(2.61)^{* * *}\end{array}$ & $\begin{array}{c}0.263 \\
(2.25)^{* *}\end{array}$ & $\begin{array}{l}0.120 \\
(1.25)\end{array}$ & $\begin{array}{c}0.233 \\
(4.40)^{* * *}\end{array}$ & $\begin{array}{c}0.210 \\
(3.43)^{* * *}\end{array}$ & $\begin{array}{c}0.189 \\
(2.69)^{* * *}\end{array}$ & $\begin{array}{c}0.418 \\
(5.47)^{* * *}\end{array}$ & $\begin{array}{l}0.095 \\
(1.03)\end{array}$ \\
\hline $\ln$ (real GDP) & $\begin{array}{c}0.223 \\
(1.76)^{*}\end{array}$ & $\begin{array}{l}-0.252 \\
(1.68)^{*}\end{array}$ & $\begin{array}{c}-0.395 \\
(2.15)^{* *}\end{array}$ & $\begin{array}{l}-0.166 \\
(1.10)\end{array}$ & $\begin{array}{c}-0.182 \\
(2.19)^{* *}\end{array}$ & $\begin{array}{c}-0.231 \\
(2.41)^{* * *}\end{array}$ & $\begin{array}{l}-0.201 \\
(1.82)^{*}\end{array}$ & $\begin{array}{l}-0.233 \\
(1.95)^{*}\end{array}$ & $\begin{array}{l}-0.038 \\
(0.27)\end{array}$ \\
\hline $\ln ($ real R\&D) & & $\begin{array}{l}0.027 \\
(0.31)\end{array}$ & $\begin{array}{l}0.028 \\
(0.26)\end{array}$ & $\begin{array}{l}0.007 \\
(0.08)\end{array}$ & $\begin{array}{l}-0.023 \\
(0.48)\end{array}$ & $\begin{array}{l}-0.043 \\
(0.77)\end{array}$ & $\begin{array}{l}-0.028 \\
(0.43)\end{array}$ & $\begin{array}{l}0.048 \\
(0.68)\end{array}$ & $\begin{array}{l}-0.035 \\
(0.42)\end{array}$ \\
\hline Observations & 215 & 215 & 215 & 215 & 215 & 215 & 215 & 215 & 215 \\
\hline Number of industries & 24 & 24 & 24 & 24 & 24 & 24 & 24 & 24 & 24 \\
\hline R-squared & 0.24 & 0.60 & 0.23 & 0.30 & 0.80 & 0.84 & 0.85 & 0.85 & 0.52 \\
\hline
\end{tabular}

Notes: Because R\&D data for shoe and leather, printing and furniture industries were not reported prior to the Reforms, we drop these industries from the regressions. Wood and lumber industry is also omitted from the regressions as we do not have export data for lumber, while we cannot separate wood from lumber for GDP and PPI. Furthermore, we exclude the pharmaceutical industry from the regression as the new regime deems pharmaceutical products patentable. Data on U.S. R\&D spending for rubber and miscellaneous plastic products in 1991 is also missing. All the citation weights for a patent are calculated from the total number of citations it receives or cites plus 1 to take into account patents with no citation. Finally, the weighting using forward citations is calculated using a fixed window of 4 years because of the truncation problem in the data. See Appendix 4 for more details. 
TABLE 3

Canadian Inventive Activity as Compared to that of Americans with Industry Fixed Effects and Country Intercept for Real Exports

\begin{tabular}{|c|c|c|c|c|c|c|c|c|c|}
\hline & \multirow[t]{3}{*}{ (1) } & (2) & (3) & (4) & (5) & (6) & (7) & (8) & \multirow[b]{3}{*}{$\begin{array}{c}\ln (E P O \\
\text { applications) } \\
\text { unweighted }\end{array}$} \\
\hline & & \multicolumn{3}{|c|}{ ln (CIPO patents) } & \multicolumn{4}{|c|}{ ln (USPTO patents) } & \\
\hline & & Unweighted & $\begin{array}{c}\text { Claims } \\
\text { weighted }\end{array}$ & $\begin{array}{c}\text { Classes } \\
\text { weighted }\end{array}$ & Unweighted & $\begin{array}{c}\text { Claims } \\
\text { weighted }\end{array}$ & $\begin{array}{c}\text { Backward } \\
\text { citations } \\
\text { weighted }\end{array}$ & $\begin{array}{c}\text { Forward } \\
\text { citation } \\
\text { weighted }\end{array}$ & \\
\hline Constant & $\begin{array}{l}-0.986 \\
(0.67)\end{array}$ & $\begin{array}{l}0.557 \\
(0.33)\end{array}$ & $\begin{array}{c}3.761 \\
(1.80)^{*}\end{array}$ & $\begin{array}{c}3.560 \\
(2.08)^{* *}\end{array}$ & $\begin{array}{c}2.206 \\
(2.35)^{* *}\end{array}$ & $\begin{array}{c}5.361 \\
(4.92)^{* * *}\end{array}$ & $\begin{array}{c}5.243 \\
(4.19)^{* * *}\end{array}$ & $\begin{array}{l}0.358 \\
(0.26)\end{array}$ & $\begin{array}{l}2.571 \\
(1.56)\end{array}$ \\
\hline Year 1984 & $\begin{array}{l}0.061 \\
(1.10)\end{array}$ & $\begin{array}{l}-0.078 \\
(1.21)\end{array}$ & $\begin{array}{l}-0.069 \\
(0.87)\end{array}$ & $\begin{array}{l}-0.102 \\
(1.58)\end{array}$ & $\begin{array}{c}0.087 \\
(2.44)^{* *}\end{array}$ & $\begin{array}{c}0.119 \\
(2.90)^{* * *}\end{array}$ & $\begin{array}{c}0.167 \\
(3.53)^{* * *}\end{array}$ & $\begin{array}{c}0.159 \\
(3.09)^{* * *}\end{array}$ & $\begin{array}{l}0.052 \\
(0.84)\end{array}$ \\
\hline Year 1985 & $\begin{array}{c}0.136 \\
(2.42)^{* *}\end{array}$ & $\begin{array}{l}-0.018 \\
(0.27)\end{array}$ & $\begin{array}{l}0.026 \\
(0.32)\end{array}$ & $\begin{array}{l}-0.035 \\
(0.53)\end{array}$ & $\begin{array}{c}0.078 \\
(2.12)^{* *}\end{array}$ & $\begin{array}{c}0.132 \\
(3.11)^{* * *}\end{array}$ & $\begin{array}{c}0.137 \\
(2.79)^{* * *}\end{array}$ & $\begin{array}{c}0.166 \\
(3.12)^{* * *}\end{array}$ & $\begin{array}{l}0.084 \\
(1.31)\end{array}$ \\
\hline Year 1986 & $\begin{array}{c}0.161 \\
(2.69)^{* * *}\end{array}$ & $\begin{array}{l}-0.117 \\
(1.65)\end{array}$ & $\begin{array}{l}-0.045 \\
(0.52)\end{array}$ & $\begin{array}{l}-0.068 \\
(0.96)\end{array}$ & $\begin{array}{c}0.144 \\
(3.70)^{* * *}\end{array}$ & $\begin{array}{c}0.237 \\
(5.25)^{* * *}\end{array}$ & $\begin{array}{c}0.252 \\
(4.87)^{* * *}\end{array}$ & $\begin{array}{c}0.228 \\
(4.04)^{* * *}\end{array}$ & $\begin{array}{c}0.229 \\
(3.35)^{* * *}\end{array}$ \\
\hline Year 1990 & $\begin{array}{l}0.091 \\
(0.92)\end{array}$ & $\begin{array}{c}-0.610 \\
(5.32)^{* * *}\end{array}$ & $\begin{array}{c}-0.249 \\
(1.78)^{*}\end{array}$ & $\begin{array}{c}-0.269 \\
(2.34)^{* *}\end{array}$ & $\begin{array}{c}0.378 \\
(5.99)^{* * *}\end{array}$ & $\begin{array}{c}0.587 \\
(8.04)^{* * *}\end{array}$ & $\begin{array}{c}0.637 \\
(7.59)^{* * *}\end{array}$ & $\begin{array}{c}0.581 \\
(6.36)^{* * *}\end{array}$ & $\begin{array}{c}0.501 \\
(4.53)^{* * *}\end{array}$ \\
\hline Year 1991 & $\begin{array}{l}0.123 \\
(1.21)\end{array}$ & $\begin{array}{c}-0.745 \\
(6.23)^{* * *}\end{array}$ & $\begin{array}{c}-0.314 \\
(2.15)^{* *}\end{array}$ & $\begin{array}{c}-0.363 \\
(3.04)^{* * *}\end{array}$ & $\begin{array}{c}0.392 \\
(5.97)^{* * *}\end{array}$ & $\begin{array}{c}0.586 \\
(7.71)^{* * *}\end{array}$ & $\begin{array}{c}0.720 \\
(8.24)^{* * * *}\end{array}$ & $\begin{array}{c}0.690 \\
(7.26)^{* * *}\end{array}$ & $\begin{array}{c}0.404 \\
(3.51)^{* * *}\end{array}$ \\
\hline Year 1992 & $\begin{array}{l}0.129 \\
(1.23)\end{array}$ & $\begin{array}{c}-0.731 \\
(5.94)^{* * *}\end{array}$ & $\begin{array}{c}-0.291 \\
(1.94)^{*}\end{array}$ & $\begin{array}{c}-0.286 \\
(2.33)^{* *}\end{array}$ & $\begin{array}{c}0.346 \\
(5.12)^{* * *}\end{array}$ & $\begin{array}{c}0.580 \\
(7.41)^{* * *}\end{array}$ & $\begin{array}{c}0.698 \\
(7.76)^{* * *}\end{array}$ & $\begin{array}{c}0.661 \\
(6.76)^{* * *}\end{array}$ & $\begin{array}{c}0.472 \\
(3.98)^{* * * *}\end{array}$ \\
\hline Year 1993 & $\begin{array}{l}0.173 \\
(1.60)\end{array}$ & $\begin{array}{c}-0.635 \\
(5.01)^{* * *}\end{array}$ & $\begin{array}{l}-0.147 \\
(0.95)\end{array}$ & $\begin{array}{l}-0.170 \\
(1.34)\end{array}$ & $\begin{array}{c}0.418 \\
(6.00)^{* * *}\end{array}$ & $\begin{array}{c}0.645 \\
(7.99)^{* * *}\end{array}$ & $\begin{array}{c}0.868 \\
(9.36)^{* * *}\end{array}$ & $\begin{array}{c}0.720 \\
(7.14)^{* * *}\end{array}$ & $\begin{array}{c}0.388 \\
(3.18)^{* * *}\end{array}$ \\
\hline Year 1994 & $\begin{array}{l}0.119 \\
(1.02)\end{array}$ & $\begin{array}{c}-0.581 \\
(4.24)^{* * *}\end{array}$ & $\begin{array}{l}-0.185 \\
(1.10)\end{array}$ & $\begin{array}{l}-0.124 \\
(0.91)\end{array}$ & $\begin{array}{c}0.504 \\
(6.69)^{* * *}\end{array}$ & $\begin{array}{c}0.784 \\
(8.99)^{* * *}\end{array}$ & $\begin{array}{c}1.003 \\
(10.00)^{* * *}\end{array}$ & $\begin{array}{c}0.731 \\
(6.71)^{* * *}\end{array}$ & $\begin{array}{c}0.441 \\
(3.33)^{* * *}\end{array}$ \\
\hline Reform x Canada & $\begin{array}{l}0.038 \\
(0.38)\end{array}$ & $\begin{array}{l}0.140 \\
(1.18)\end{array}$ & $\begin{array}{l}-0.098 \\
(0.68)\end{array}$ & $\begin{array}{l}-0.045 \\
(0.38)\end{array}$ & $\begin{array}{l}0.010 \\
(0.16)\end{array}$ & $\begin{array}{l}-0.023 \\
(0.31)\end{array}$ & $\begin{array}{l}-0.072 \\
(0.83)\end{array}$ & $\begin{array}{l}0.030 \\
(0.32)\end{array}$ & $\begin{array}{l}-0.042 \\
(0.37)\end{array}$ \\
\hline $\ln$ (real export) & $\begin{array}{l}0.035 \\
(0.30)\end{array}$ & $\begin{array}{l}0.153 \\
(1.12)\end{array}$ & $\begin{array}{l}0.082 \\
(0.49)\end{array}$ & $\begin{array}{l}-0.057 \\
(0.42)\end{array}$ & $\begin{array}{l}0.113 \\
(1.51)\end{array}$ & $\begin{array}{l}0.081 \\
(0.93)\end{array}$ & $\begin{array}{l}0.056 \\
(0.56)\end{array}$ & $\begin{array}{c}0.267 \\
(2.46)^{* *}\end{array}$ & $\begin{array}{l}0.121 \\
(0.92)\end{array}$ \\
\hline $\ln ($ real GDP) & $\begin{array}{c}0.233 \\
(1.79)^{*}\end{array}$ & $\begin{array}{l}-0.222 \\
(1.45)\end{array}$ & $\begin{array}{l}-0.337 \\
(1.81)^{*}\end{array}$ & $\begin{array}{l}-0.110 \\
(0.72)\end{array}$ & $\begin{array}{l}-0.144 \\
(1.72)^{*}\end{array}$ & $\begin{array}{l}-0.190 \\
(1.96)^{*}\end{array}$ & $\begin{array}{l}-0.158 \\
(1.42)\end{array}$ & $\begin{array}{l}-0.186 \\
(1.53)\end{array}$ & $\begin{array}{l}-0.047 \\
(0.32)\end{array}$ \\
\hline $\ln ($ real R\&D) & & $\begin{array}{l}0.025 \\
(0.28)\end{array}$ & $\begin{array}{l}0.023 \\
(0.22)\end{array}$ & $\begin{array}{l}0.003 \\
(0.03)\end{array}$ & $\begin{array}{l}-0.026 \\
(0.55)\end{array}$ & $\begin{array}{l}-0.046 \\
(0.84)\end{array}$ & $\begin{array}{l}-0.031 \\
(0.48)\end{array}$ & $\begin{array}{l}0.044 \\
(0.64)\end{array}$ & $\begin{array}{l}-0.035 \\
(0.41)\end{array}$ \\
\hline ln (real export) x Canada & $\begin{array}{l}0.052 \\
(0.36)\end{array}$ & $\begin{array}{l}0.163 \\
(0.98)\end{array}$ & $\begin{array}{l}0.309 \\
(1.52)\end{array}$ & $\begin{array}{c}0.302 \\
(1.81)^{*}\end{array}$ & $\begin{array}{c}0.206 \\
(2.24)^{* *}\end{array}$ & $\begin{array}{c}0.221 \\
(2.08)^{* * *}\end{array}$ & $\begin{array}{c}0.228 \\
(1.87)^{*}\end{array}$ & $\begin{array}{c}0.259 \\
(1.95)^{*}\end{array}$ & $\begin{array}{l}-0.045 \\
(0.28)\end{array}$ \\
\hline Observations & 215 & 215 & 215 & 215 & 215 & 215 & 215 & 215 & 215 \\
\hline Number of industries & 24 & 24 & 24 & 24 & 24 & 24 & 24 & 24 & 24 \\
\hline R-squared & 0.24 & 0.60 & 0.24 & 0.31 & 0.81 & 0.84 & 0.86 & 0.86 & 0.52 \\
\hline
\end{tabular}

Absolute value of $t$ statistics in parentheses

* significant at $10 \%$; ** significant at $5 \%$; *** significant at $1 \%$

Notes: See Table 2. 
TABLE 4

Canadian and American Inventive Activity: including Industry Fixed Effects, Country Intercept and Time Intercept for Real Exports

\begin{tabular}{|c|c|c|c|c|c|c|c|c|c|}
\hline & \multirow[b]{2}{*}{$\ln ($ real R\&D) } & (2) & $\begin{array}{c}\text { (3) } \\
\text { CIPO pate }\end{array}$ & (4) & \multicolumn{4}{|c|}{ ln (USPTO patents) } & \multirow[b]{2}{*}{$\begin{array}{c}\ln (\mathrm{EPO} \\
\text { applications) } \\
\text { unweighted }\end{array}$} \\
\hline & & Unweighted & $\begin{array}{c}\text { Claims } \\
\text { weighted }\end{array}$ & $\begin{array}{c}\text { Classes } \\
\text { weighted }\end{array}$ & Unweighted & $\begin{array}{c}\text { Claims } \\
\text { weighted }\end{array}$ & $\begin{array}{c}\text { Backward } \\
\text { citations } \\
\text { weighted } \\
\end{array}$ & $\begin{array}{c}\text { Forward } \\
\text { citation } \\
\text { weighted } \\
\end{array}$ & \\
\hline Constant & $\begin{array}{l}-1.167 \\
(0.81)\end{array}$ & $\begin{array}{l}0.599 \\
(0.35)\end{array}$ & $\begin{array}{c}3.828 \\
(1.83)^{*}\end{array}$ & $\begin{array}{c}3.619 \\
(2.11)^{* *}\end{array}$ & $\begin{array}{c}2.187 \\
(2.32)^{* *}\end{array}$ & $\begin{array}{c}5.361 \\
(4.90)^{* * *}\end{array}$ & $\begin{array}{c}5.296 \\
(4.22)^{* * *}\end{array}$ & $\begin{array}{l}0.266 \\
(0.20)\end{array}$ & $\begin{array}{l}2.533 \\
(1.53)\end{array}$ \\
\hline Year 1984 & $\begin{array}{l}0.060 \\
(1.11)\end{array}$ & $\begin{array}{l}-0.079 \\
(1.21)\end{array}$ & $\begin{array}{l}-0.070 \\
(0.88)\end{array}$ & $\begin{array}{l}-0.103 \\
(1.59)\end{array}$ & $\begin{array}{c}0.087 \\
(2.44)^{* *}\end{array}$ & $\begin{array}{c}0.119 \\
(2.89)^{* * *}\end{array}$ & $\begin{array}{c}0.166 \\
(3.51)^{* * *}\end{array}$ & $\begin{array}{c}0.160 \\
(3.11)^{* * *}\end{array}$ & $\begin{array}{l}0.053 \\
(0.84)\end{array}$ \\
\hline Year 1985 & $\begin{array}{c}0.136 \\
(2.46)^{* *}\end{array}$ & $\begin{array}{l}-0.019 \\
(0.29)\end{array}$ & $\begin{array}{l}0.025 \\
(0.30)\end{array}$ & $\begin{array}{l}-0.037 \\
(0.55)\end{array}$ & $\begin{array}{c}0.078 \\
(2.13)^{* *}\end{array}$ & $\begin{array}{c}0.132 \\
(3.10)^{* * *}\end{array}$ & $\begin{array}{c}0.135 \\
(2.76)^{* * *}\end{array}$ & $\begin{array}{c}0.168 \\
(3.17)^{* * *}\end{array}$ & $\begin{array}{l}0.085 \\
(1.32)\end{array}$ \\
\hline Year 1986 & $\begin{array}{c}0.163 \\
(2.79)^{* * * *}\end{array}$ & $\begin{array}{l}-0.119 \\
(1.67)^{*}\end{array}$ & $\begin{array}{l}-0.048 \\
(0.55)\end{array}$ & $\begin{array}{l}-0.071 \\
(1.00)\end{array}$ & $\begin{array}{c}0.145 \\
(3.70)^{* * *}\end{array}$ & $\begin{array}{c}0.237 \\
(5.23)^{* * *}\end{array}$ & $\begin{array}{c}0.250 \\
(4.81)^{* * *}\end{array}$ & $\begin{array}{c}0.232 \\
(4.11)^{* * *}\end{array}$ & $\begin{array}{c}0.231 \\
(3.36)^{* * *}\end{array}$ \\
\hline Year 1990 & $\begin{array}{c}-1.483 \\
(2.86)^{* * * *}\end{array}$ & $\begin{array}{l}-0.324 \\
(0.51)\end{array}$ & $\begin{array}{l}0.207 \\
(0.27)\end{array}$ & $\begin{array}{l}0.138 \\
(0.22)\end{array}$ & $\begin{array}{l}0.250 \\
(0.72)\end{array}$ & $\begin{array}{l}0.584 \\
(1.45)\end{array}$ & $\begin{array}{c}0.996 \\
(2.15)^{* *}\end{array}$ & $\begin{array}{l}-0.044 \\
(0.09)\end{array}$ & $\begin{array}{l}0.241 \\
(0.39)\end{array}$ \\
\hline Year 1991 & $\begin{array}{c}-1.457 \\
(2.80)^{* * *}\end{array}$ & $\begin{array}{l}-0.458 \\
(0.72)\end{array}$ & $\begin{array}{l}0.143 \\
(0.18)\end{array}$ & $\begin{array}{l}0.045 \\
(0.07)\end{array}$ & $\begin{array}{l}0.263 \\
(0.75)\end{array}$ & $\begin{array}{l}0.584 \\
(1.44)\end{array}$ & $\begin{array}{c}1.080 \\
(2.32)^{* *}\end{array}$ & $\begin{array}{l}0.063 \\
(0.13)\end{array}$ & $\begin{array}{l}0.143 \\
(0.23)\end{array}$ \\
\hline Year 1992 & $\begin{array}{c}-1.461 \\
(2.79)^{* * *}\end{array}$ & $\begin{array}{l}-0.442 \\
(0.69)\end{array}$ & $\begin{array}{l}0.170 \\
(0.22)\end{array}$ & $\begin{array}{l}0.124 \\
(0.19)\end{array}$ & $\begin{array}{l}0.216 \\
(0.61)\end{array}$ & $\begin{array}{l}0.577 \\
(1.42)\end{array}$ & $\begin{array}{c}1.059 \\
(2.26)^{* *}\end{array}$ & $\begin{array}{l}0.030 \\
(0.06)\end{array}$ & $\begin{array}{l}0.209 \\
(0.34)\end{array}$ \\
\hline Year 1993 & $\begin{array}{c}-1.424 \\
(2.70)^{* * *}\end{array}$ & $\begin{array}{l}-0.346 \\
(0.54)\end{array}$ & $\begin{array}{l}0.314 \\
(0.40)\end{array}$ & $\begin{array}{l}0.242 \\
(0.38)\end{array}$ & $\begin{array}{l}0.288 \\
(0.82)\end{array}$ & $\begin{array}{l}0.642 \\
(1.57)\end{array}$ & $\begin{array}{c}1.231 \\
(2.62)^{* * *}\end{array}$ & $\begin{array}{l}0.088 \\
(0.17)\end{array}$ & $\begin{array}{l}0.124 \\
(0.20)\end{array}$ \\
\hline Year 1994 & $\begin{array}{c}-1.487 \\
(2.79)^{* * *}\end{array}$ & $\begin{array}{l}-0.289 \\
(0.44)\end{array}$ & $\begin{array}{l}0.281 \\
(0.35)\end{array}$ & $\begin{array}{l}0.290 \\
(0.45)\end{array}$ & $\begin{array}{l}0.373 \\
(1.04)\end{array}$ & $\begin{array}{c}0.782 \\
(1.89)^{*}\end{array}$ & $\begin{array}{c}1.368 \\
(2.88)^{* * *}\end{array}$ & $\begin{array}{l}0.094 \\
(0.18)\end{array}$ & $\begin{array}{l}0.175 \\
(0.28)\end{array}$ \\
\hline Reform x Canada & $\begin{array}{l}0.070 \\
(0.70)\end{array}$ & $\begin{array}{l}0.134 \\
(1.12)\end{array}$ & $\begin{array}{l}-0.108 \\
(0.74)\end{array}$ & $\begin{array}{l}-0.053 \\
(0.45)\end{array}$ & $\begin{array}{l}0.013 \\
(0.20)\end{array}$ & $\begin{array}{l}-0.023 \\
(0.31)\end{array}$ & $\begin{array}{l}-0.079 \\
(0.91)\end{array}$ & $\begin{array}{l}0.044 \\
(0.46)\end{array}$ & $\begin{array}{l}-0.037 \\
(0.32)\end{array}$ \\
\hline ln (real export) & $\begin{array}{l}0.025 \\
(0.22)\end{array}$ & $\begin{array}{l}0.155 \\
(1.13)\end{array}$ & $\begin{array}{l}0.085 \\
(0.51)\end{array}$ & $\begin{array}{l}-0.055 \\
(0.40)\end{array}$ & $\begin{array}{l}0.112 \\
(1.49)\end{array}$ & $\begin{array}{l}0.081 \\
(0.93)\end{array}$ & $\begin{array}{l}0.058 \\
(0.58)\end{array}$ & $\begin{array}{c}0.263 \\
(2.43)^{* *}\end{array}$ & $\begin{array}{l}0.119 \\
(0.90)\end{array}$ \\
\hline $\ln$ (real GDP) & $\begin{array}{l}0.182 \\
(1.43)\end{array}$ & $\begin{array}{l}-0.215 \\
(1.40)\end{array}$ & $\begin{array}{l}-0.326 \\
(1.74)^{*}\end{array}$ & $\begin{array}{l}-0.100 \\
(0.65)\end{array}$ & $\begin{array}{l}-0.147 \\
(1.74)^{*}\end{array}$ & $\begin{array}{l}-0.190 \\
(1.94)^{*}\end{array}$ & $\begin{array}{l}-0.150 \\
(1.33)\end{array}$ & $\begin{array}{l}-0.201 \\
(1.65)\end{array}$ & $\begin{array}{l}-0.053 \\
(0.36)\end{array}$ \\
\hline $\ln ($ real R\&D) & & $\begin{array}{l}0.034 \\
(0.38)\end{array}$ & $\begin{array}{l}0.038 \\
(0.35)\end{array}$ & $\begin{array}{l}0.016 \\
(0.18)\end{array}$ & $\begin{array}{l}-0.030 \\
(0.62)\end{array}$ & $\begin{array}{l}-0.046 \\
(0.81)\end{array}$ & $\begin{array}{l}-0.019 \\
(0.29)\end{array}$ & $\begin{array}{l}0.024 \\
(0.33)\end{array}$ & $\begin{array}{l}-0.043 \\
(0.50)\end{array}$ \\
\hline ln (real export) x Canada & $\begin{array}{l}0.123 \\
(0.86)\end{array}$ & $\begin{array}{l}0.150 \\
(0.88)\end{array}$ & $\begin{array}{l}0.288 \\
(1.39)\end{array}$ & $\begin{array}{c}0.283 \\
(1.67)^{*}\end{array}$ & $\begin{array}{c}0.212 \\
(2.27)^{* *}\end{array}$ & $\begin{array}{c}0.221 \\
(2.04)^{* *}\end{array}$ & $\begin{array}{c}0.212 \\
(1.71)^{*}\end{array}$ & $\begin{array}{c}0.288 \\
(2.14)^{* *}\end{array}$ & $\begin{array}{l}-0.033 \\
(0.20)\end{array}$ \\
\hline ln (real export) x Reform & $\begin{array}{c}0.085 \\
(3.09)^{* * *}\end{array}$ & $\begin{array}{l}-0.016 \\
(0.46)\end{array}$ & $\begin{array}{l}-0.025 \\
(0.60)\end{array}$ & $\begin{array}{l}-0.022 \\
(0.65)\end{array}$ & $\begin{array}{l}0.007 \\
(0.37)\end{array}$ & $\begin{array}{l}0.000 \\
(0.01)\end{array}$ & $\begin{array}{l}-0.019 \\
(0.79)\end{array}$ & $\begin{array}{l}0.034 \\
(1.27)\end{array}$ & $\begin{array}{l}0.014 \\
(0.43)\end{array}$ \\
\hline Observations & 215 & 215 & 215 & 215 & 215 & 215 & 215 & 215 & 215 \\
\hline Number of industries & 24 & 24 & 24 & 24 & 24 & 24 & 24 & 24 & 24 \\
\hline R-squared & 0.28 & 0.60 & 0.25 & 0.31 & 0.81 & 0.84 & 0.86 & 0.86 & 0.52 \\
\hline
\end{tabular}

Absolute value of $\mathrm{t}$ statistics in parentheses

$*$ significant at $10 \%$; ** significant at $5 \%$; *** significant at $1 \%$

Notes: See Table 2. 
TABLE 5

Impact of the Reforms on Canadian Domestic-oriented Industries: including Industry Fixed Effects, Country Intercept and Time Intercept for Real Exports

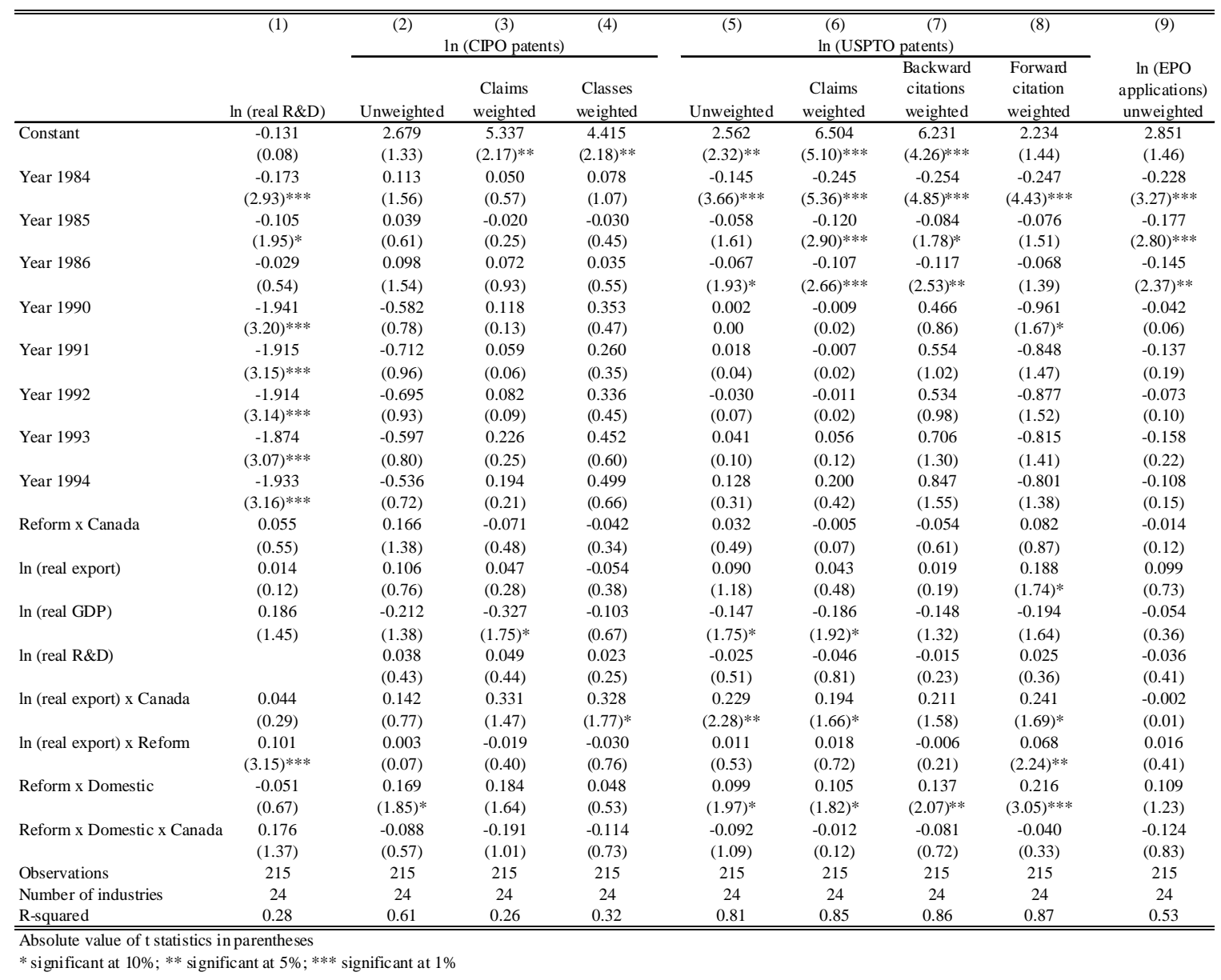

Notes: Canadian industries that we classify as one that relied on foreign markets include (1) food, beverage and tobacco, (2) paper and allied products, (3) petroleum and coal products, (4) chemical and allied products (except drugs), (5) primary metal industries, (6) fabricated metal products, (7) industrial machinery and equipment, and (8) transportation and equipment. For these eight industries, the domestic dummy takes on 0 whether they were Canadian or American. Also, see Table 2. 
TABLE 6

DISTRIBUTION OF USPTO PATENTS GRANTED TO CANADIANS BY TYPES OF OWNERSHIP

\begin{tabular}{|c|c|c|c|c|c|c|c|c|c|c|c|c|}
\hline \multirow[b]{2}{*}{ Share of patents (\%) } & \multicolumn{4}{|c|}{ Pre-reform years } & \multicolumn{3}{|c|}{ Inter-reform years } & \multicolumn{5}{|c|}{ Post-reform years } \\
\hline & 1983 & 1984 & 1985 & 1986 & 1987 & 1988 & 1989 & 1990 & 1991 & 1992 & 1993 & 1994 \\
\hline Not assigned & 34.3 & 34.3 & 33.4 & 40.2 & 36.8 & 37.7 & 35.6 & 37.8 & 39.3 & 34.9 & 34.8 & 33.2 \\
\hline Assigned to individuals & 1.4 & 1.0 & 1.0 & 1.5 & 1.4 & 1.3 & 1.6 & 1.8 & 1.2 & 1.9 & 1.6 & 1.5 \\
\hline Assigned to small firms & 36.7 & 33.7 & 34.7 & 31.9 & 33.7 & 31.6 & 30.7 & 27.5 & 25.9 & 29.4 & 29.2 & 32.4 \\
\hline Assigned to large firms & 27.7 & 31.0 & 30.9 & 26.5 & 28.1 & 29.3 & 32.1 & 32.9 & 33.5 & 33.8 & 34.5 & 32.9 \\
\hline
\end{tabular}

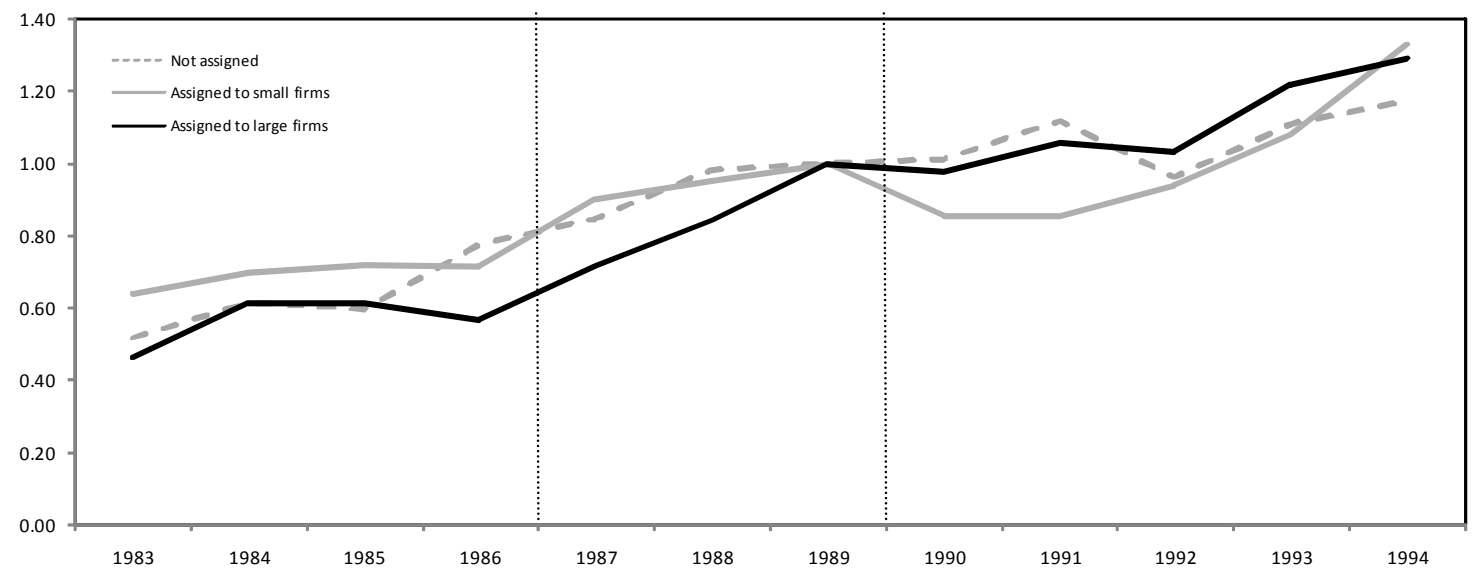

FIGURE 7

CANADIAN PATENTING IN THE U.S. BY TYPES OF OWNERSHIP (NORMALIZED) 


\section{TABLE 7}

Patenting in the U.S. by Small Canadian Entities as Compared to that of Large Canadian Corporations with Industry Fixed Effects

\begin{tabular}{|c|c|c|c|c|}
\hline & (1) & $(2)$ & (3) & (4) \\
\hline & \multicolumn{4}{|c|}{ ln (USPTO patents) } \\
\hline & Unweighted & $\begin{array}{c}\text { Claims } \\
\text { weighted }\end{array}$ & $\begin{array}{l}\text { Backward } \\
\text { citations } \\
\text { weighted }\end{array}$ & $\begin{array}{c}\text { Forward } \\
\text { citation } \\
\text { weighted }\end{array}$ \\
\hline Constant & $\begin{array}{l}-1.430 \\
(0.94)\end{array}$ & $\begin{array}{l}0.965 \\
(0.50)\end{array}$ & $\begin{array}{l}2.327 \\
(1.18)\end{array}$ & $\begin{array}{l}-3.112 \\
(1.57)\end{array}$ \\
\hline Year 1984 & $\begin{array}{c}0.144 \\
(2.46)^{* *}\end{array}$ & $\begin{array}{c}0.246 \\
(3.31)^{* * *}\end{array}$ & $\begin{array}{c}0.287 \\
(3.77)^{* * *}\end{array}$ & $\begin{array}{c}0.251 \\
(3.27)^{* * *}\end{array}$ \\
\hline Year 1985 & $\begin{array}{c}0.122 \\
(1.99)^{* *}\end{array}$ & $\begin{array}{c}0.241 \\
(3.10)^{* * *}\end{array}$ & $\begin{array}{c}0.241 \\
(3.03)^{* * *}\end{array}$ & $\begin{array}{c}0.242 \\
(3.02)^{* * *}\end{array}$ \\
\hline Year 1986 & $\begin{array}{c}0.166 \\
(2.51)^{* *}\end{array}$ & $\begin{array}{c}0.292 \\
(3.48)^{* * *}\end{array}$ & $\begin{array}{c}0.351 \\
(4.09)^{* * *}\end{array}$ & $\begin{array}{c}0.243 \\
(2.81)^{* * *}\end{array}$ \\
\hline Year 1990 & $\begin{array}{c}0.592 \\
(7.64)^{* * *}\end{array}$ & $\begin{array}{c}0.871 \\
(8.86)^{* * *}\end{array}$ & $\begin{array}{c}0.887 \\
(8.80)^{* * *}\end{array}$ & $\begin{array}{c}0.885 \\
(8.73)^{* * *}\end{array}$ \\
\hline Year 1991 & $\begin{array}{c}0.628 \\
(8.05)^{* * *}\end{array}$ & $\begin{array}{c}0.891 \\
(9.00)^{* * *}\end{array}$ & $\begin{array}{c}1.017 \\
(10.03)^{* * *}\end{array}$ & $\begin{array}{c}1.103 \\
(10.81)^{* * *}\end{array}$ \\
\hline Year 1992 & $\begin{array}{c}0.518 \\
(6.44)^{* * *}\end{array}$ & $\begin{array}{c}0.826 \\
(8.08)^{* * *}\end{array}$ & $\begin{array}{c}0.884 \\
(8.45)^{* * *}\end{array}$ & $\begin{array}{c}0.960 \\
(9.12)^{* * *}\end{array}$ \\
\hline Year 1993 & $\begin{array}{c}0.630 \\
(7.17)^{* * *}\end{array}$ & $\begin{array}{c}0.907 \\
(8.14)^{* * *}\end{array}$ & $\begin{array}{c}1.164 \\
(10.19)^{* * *}\end{array}$ & $\begin{array}{c}1.050 \\
(9.13)^{* * *}\end{array}$ \\
\hline Year 1994 & $\begin{array}{c}0.697 \\
(7.14)^{* * *}\end{array}$ & $\begin{array}{c}1.045 \\
(8.45)^{* * *}\end{array}$ & $\begin{array}{c}1.256 \\
(9.90)^{* * *}\end{array}$ & $\begin{array}{c}1.019 \\
(7.99)^{* * *}\end{array}$ \\
\hline Reform x Small & $\begin{array}{c}-0.209 \\
(3.99)^{* * *}\end{array}$ & $\begin{array}{c}-0.315 \\
(4.73)^{* * *}\end{array}$ & $\begin{array}{c}-0.274 \\
(4.01)^{* * *}\end{array}$ & $\begin{array}{c}-0.332 \\
(4.84)^{* * *}\end{array}$ \\
\hline ln (real export) & $\begin{array}{c}0.280 \\
(3.30)^{* * *}\end{array}$ & $\begin{array}{c}0.304 \\
(2.82)^{* * *}\end{array}$ & $\begin{array}{c}0.204 \\
(1.85)^{*}\end{array}$ & $\begin{array}{c}0.464 \\
(4.19)^{* * *}\end{array}$ \\
\hline $\ln ($ real GDP) & $\begin{array}{l}-0.185 \\
(1.46)\end{array}$ & $\begin{array}{l}-0.297 \\
(1.84)^{*}\end{array}$ & $\begin{array}{l}-0.287 \\
(1.74)^{*}\end{array}$ & $\begin{array}{l}-0.287 \\
(1.72)^{*}\end{array}$ \\
\hline $\ln ($ real R\&D) & $\begin{array}{l}-0.045 \\
(0.59)\end{array}$ & $\begin{array}{l}-0.048 \\
(0.49)\end{array}$ & $\begin{array}{l}-0.054 \\
(0.54)\end{array}$ & $\begin{array}{l}0.138 \\
(1.37)\end{array}$ \\
\hline Observations & 216 & 216 & 216 & 216 \\
\hline Number of industries & 24 & 24 & 24 & 24 \\
\hline R-squared & 0.69 & 0.71 & 0.75 & 0.79 \\
\hline
\end{tabular}

Absolute value of $t$ statistics in parentheses

* significant at $10 \%$; ** significant at $5 \%$; ** significant at $1 \%$

Notes: See Table 2. 


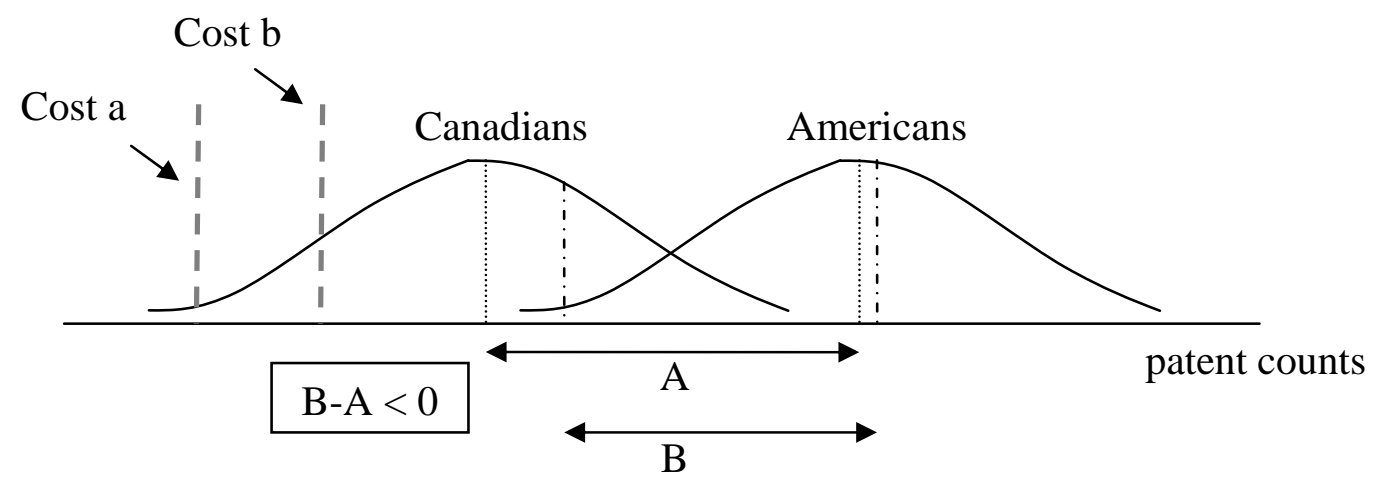

FIGURE A1

The Effects of MaintenAnCE FEes on Patenting

TABLE A1

Characteristics of Canadian Manufacturing Industries in 1989

\begin{tabular}{|c|c|c|c|c|c|c|c|c|}
\hline Industry & $\begin{array}{r}\text { R\&D } \\
\text { (million } \\
\text { CAD) }\end{array}$ & $\begin{array}{r}\text { No. of } \\
\text { CIPO patent } \\
\text { grants }\end{array}$ & $\begin{array}{r}\text { No. of } \\
\text { USPTO } \\
\text { patent grants } \\
\end{array}$ & $\begin{array}{r}\text { No. of EPO } \\
\text { patent } \\
\text { applications }\end{array}$ & $\begin{array}{r}\text { Export } \\
\text { (million } \\
\text { CAD) }\end{array}$ & $\begin{array}{r}\text { GDP } \\
\text { (million } \\
\text { CAD) }\end{array}$ & $\begin{array}{r}\text { R\&D } \\
\text { spending per } \\
\text { CIPO patent } \\
\end{array}$ & $\begin{array}{r}\text { Share of } \\
\text { USPTO } \\
\text { patents } \\
\text { owned by } \\
\text { large } \\
\text { corporations } \\
\text { (percent) }\end{array}$ \\
\hline Food, Beverage and Tobacco & 69 & 19 & 25 & 5 & 8,914 & 14,375 & 3.63 & 28.0 \\
\hline Textile and Apparel & 46 & 22 & 26 & 5 & 1,271 & 5,053 & 2.09 & 34.6 \\
\hline Shoe and Leather & n.a. & 8 & 10 & 2 & 183 & 544 & п.a & 20.0 \\
\hline Lumber and wood products & 18 & 29 & 25 & 3 & n.a. & 4,848 & 0.62 & 16.0 \\
\hline Paper and allied products & 151 & 24 & 25 & 8 & 8,544 & 9,856 & 6.29 & 20.0 \\
\hline Printing and publishing & 8 & 8 & 9 & 3 & 594 & 3,557 & 1.00 & 33.3 \\
\hline Petroleum and coal products & 131 & 105 & 142 & 70 & 9,137 & 640 & 1.25 & 53.5 \\
\hline Chemical and allied products except pharmaceuticals & 199 & 12 & 6 & 7 & 5,638 & 9,235 & 16.58 & 50.0 \\
\hline Pharmaceuticals & 177 & 37 & 46 & 23 & 222 & 1,914 & 4.78 & 54.3 \\
\hline Rubber and miscellaneous plastic products & 19 & 111 & 137 & 46 & 2,168 & 4,060 & 0.17 & 25.5 \\
\hline Stone, clay and glass products & 20 & 34 & 35 & 9 & 950 & 3,746 & 0.59 & 28.6 \\
\hline Primary metal industries & 162 & 23 & 32 & 7 & 8,996 & 8,117 & 7.04 & 50.0 \\
\hline Fabricated metal products & 41 & 152 & 177 & 40 & 8,996 & 6,750 & 0.27 & 25.4 \\
\hline Industrial machinery and equipment & 96 & 490 & 558 & 157 & 12,330 & 6,186 & 0.20 & 28.7 \\
\hline Electronic and other electric equipment & 1,435 & 200 & 272 & 55 & 5,484 & 12,936 & 7.18 & 43.0 \\
\hline Transportation equipment & 1,302 & 58 & 80 & 11 & 34,653 & 14,734 & 22.45 & 18.8 \\
\hline Furniture and fix tures & 3 & 22 & 22 & 3 & 1,100 & 2,710 & 0.14 & 13.6 \\
\hline
\end{tabular}

Notes: EPO data are collected from OECD StatExtracts which only provides application data. 


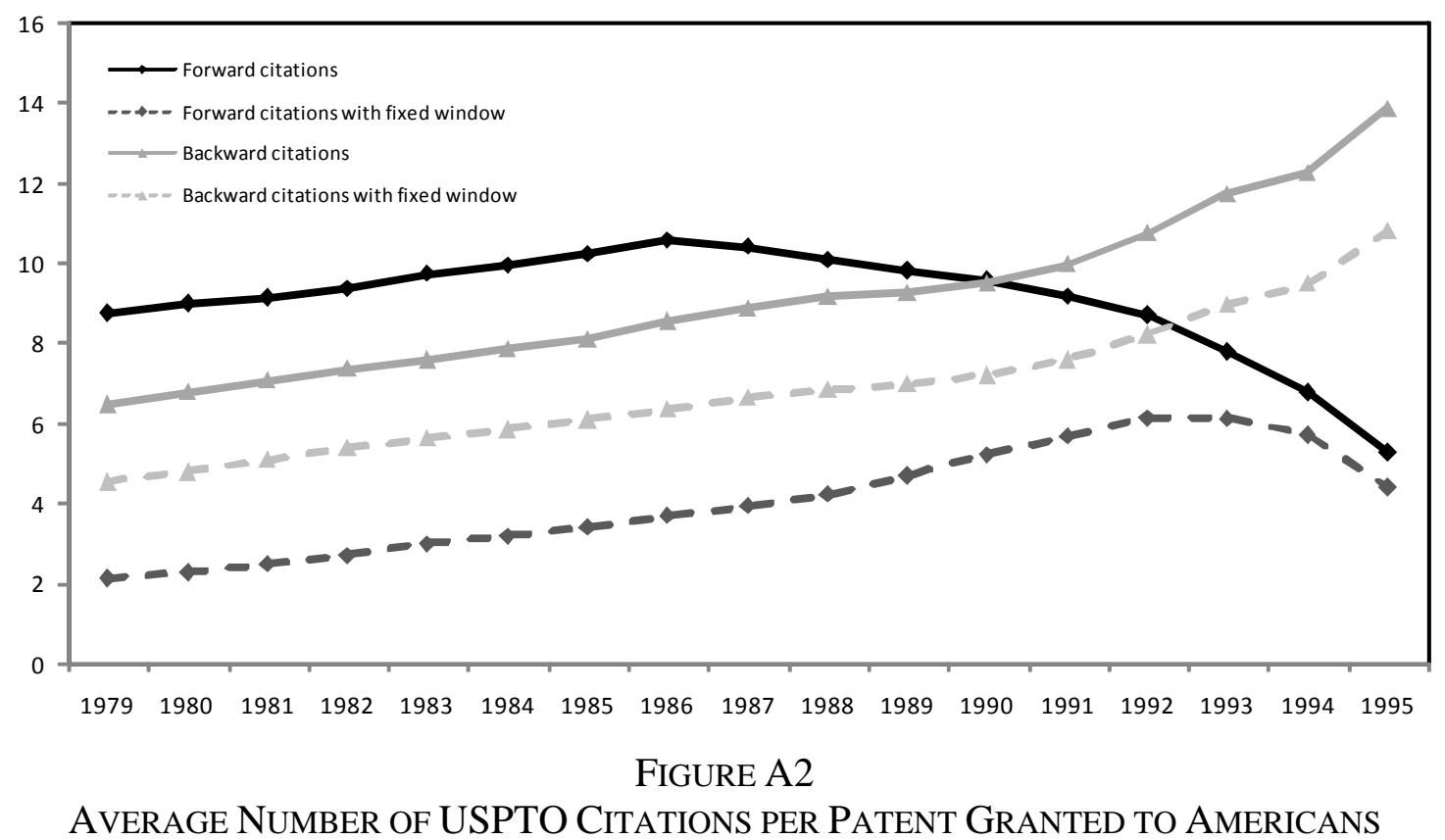

Notes: The fixed window is 4 years for forward citations and 20 years for backward citations. 